\title{
分子间卤键控制的氢键芳香酰胺折叠体组装
}

\author{
许艳艳 ${ }^{a}$ 刘传志 $a, b$ 王 辉 $a$ 张丹维 $*, a$ 黎占亭 $*, a$
}

$\left({ }^{a}\right.$ 复旦大学化学系 上海市分子催化和功能材料重点实验室 上海 200438)

( $b$ 商丘师范学院化学系 河南商丘 476000)

\begin{abstract}
摘要 报道了六个分子内氢键诱导的芳香酰胺折叠体的合成, 其多步合成中最后一步都通过形成腙键完成. 所有分子 的两端都引入三氟一碘代苯作为卤键供体及吡啶作为卤键受体. 分子间形成的 $\mathrm{I} \cdots \mathrm{N}$ 卤键及其它卤键被用于调控折叠 体骨架在固体中的自组装结构. 晶体结构揭示, 分子间卤键可以诱导不同分子形成扩展的之字形阵列, 二聚体大环和 超分子螺旋结构. 当分子两端的卤键供体和受体平行排列时，折叠体倾向于形成超分子二聚体大环. 长的四聚体和五 聚体折叠结构两端的卤键供体和受体形成大的夹角，展示出不同的卤键模式. 两个分子的端位碘原子与甲醇或水形成 $\mathrm{I} \cdots \mathrm{O}$ 卤键, 其中一个五聚体分子与甲醇通过卤键形成超分子单股螺旋结构. 另一个五聚体通过分子间 $\mathrm{I} \cdots \mathrm{O}=\mathrm{C}$ 卤键形 成另一种超分子单股螺旋. 两个单股螺旋进一步相互堆积, 形成新的超分子双股螺旋阵列.
\end{abstract}

关键词＼cjkstart卤键；氢键；折叠体；螺旋；晶体工程；大环化合物；芳香酰胺；腙

\section{Intermolecular Halogen Bonding-Controlled Self-Assembly of Hydrogen Bonded Aromatic Amide Foldamers}

\author{
$\mathrm{Xu}, \operatorname{Yanyan}^{a}$ \\ Liu, Chuanzhi ${ }^{a, b}$ \\ Wang, Hui ${ }^{a}$ \\ Zhang, Danwei*,a \\ Li, Zhanting*,a \\ ( ${ }^{a}$ Department of Chemistry, Shanghai Key Laboratory of Molecular Catalysis and Innovative Materials, Shanghai 200438) \\ ( ${ }^{b}$ Department of Chemistry, Shangqiu Normal University, Shangqiu, Henan 476000)
}

\begin{abstract}
Six intramolecular hydrogen bonding-induced aromatic amide foldamers have been prepared through the formation of the hydrazone bond in the last step. The compounds are attached with one trifluoroiodobenzene as halogen donor and one pyridine ring as halogen bonding acceptor. Intermolecular $\mathrm{I} \cdots \mathrm{N}$ halogen bond formed by the above two units and other kinds of halogen bonds are designed to modulate the stacking of the compounds in the solid state. It is revealed that intermolecular halogen bonding can induce the molecules to form extended zigzag arrays, dimeric macrocycles or supramolecular helices. The formation of the dimeric macrocycles is favored when the halogen bond donor and acceptor are located in a parallel manner. Longer tetrameric and pentameric sequences give rise to more curved, crescent conformations, with the two halogen bonding donor and acceptor on the ends to form a large angle. For two compounds, polar methanol or water prevents the formation of the intermolecular end-to-end halogen bonding by forming $\mathrm{I} \cdots \mathrm{O}$ halogen bonding. The pentameric compound is connected by methanol to form supramolecular single helices. For another pentameric compound, strong $\mathrm{I} \cdots \mathrm{O}=\mathrm{C}$ halogen bonding is found to induce the backbone to self-assemble into supramolecular single helices. The single helices further stack to afford supramolecular double helix arrays.
\end{abstract}

Keywords halogen bond; hydrogen bond; foldamer; helix; crystal engineering; macrocycle; aromatic amide; hydrazone

\section{Introduction}

In the past two decades, intramolecularly hydrogen bonding-induced aromatic foldamers have attracted great attention of chemists due to their fascinating structures and versatile functions, ${ }^{[1]}$ which include guest recognition, ${ }^{[2]}$ transmembrane transport ${ }^{[3]}$ and reaction acceleration. ${ }^{[4]}$ To explore the potentials of crescent foldamers, intermolecular hydrogen bonding has been used to "glue" short backbones to produce supramolecular tubular polymers, ${ }^{[5]}$ which can enhance transmembrane transportation of water ${ }^{[6]}$ We recently reported that, with intermolecular halogen bonding as driving force, hydrogen bonded aromatic amide foldamers can self-assemble into supramolecular double and

\footnotetext{
* Corresponding authors. E-mail: zhangdw@fudan.edu.cn; ztli@fudan.edu.cn

Received February 2, 2021; revised March 5, 2021; published online March 25, 2021.

Project supported by the National Natural Science Foundation of China (Nos. 21772026, 21890732, 21890730).

国家自然科学基金(Nos. 21772026, 21890732, 21890730)资助项目.
} 
quadruple helices and macrocycles of varying sizes. ${ }^{[7]}$ Given the wide applications of hydrogen and halogen bonding in crystal engineering and self-assembly, ${ }^{[8-9]}$ it would be valuable to study the effect of the backbone length and shape on the self-assembling pattern of this kind of aromatic foldamers or folded segments. We herein describe the synthesis of six new aromatic amide foldamers, the ends of which are attached with an iodotrifluorobenzene unit as halogen donor and a pyridine unit as halogen acceptor. Their crystal structures reveal that, depending on the length of their crescent backbones, the foldamers can form supramolecular macrocycles, zigzag and helical arrays, which are stabilized by intermolecular $\mathrm{I} \cdots \mathrm{N}$ or $\mathrm{I} \cdots \mathrm{O}=\mathrm{C}$ halogen bonding.

\section{Results and discussion}

A number of intramolecularly hydrogen bonded linear aromatic amide compounds were prepared, which bear an iodotrifluorobenzene unit as halogen donor and a pyridine unit as halogen acceptor on the two ends. The crystal structures of compounds $\mathbf{1} \sim \mathbf{6}$ (Scheme 1) were obtained using different conditions for the growth of single crystals suitable for X-ray diffraction analysis. The compounds were prepared through the formation of a hydrazone bond as the last step because the hydrazone derivatives can be generated under mild, neutral reaction conditions and the hydrazone bond may form two configurational isomers. ${ }^{[10]}$ This isomerization would cause one backbone to produce two different orientations of the halogen bonding donor and acceptor. A systematic study of crystal structures would reveal the combined influence of this isomerization, intramolecular hydrogen bonding as well as intermolecular halogen bonding on the conformation and aggregation of the molecule in the solid state. For all the compounds, iso-butoxy groups were introduced to endow strong intramolecular $\mathrm{O} \cdots \mathrm{H}-\mathrm{N}$ hydrogen bonding, reasonable solubility as well as good crystallinity. ${ }^{[1]}$ The intramolecular $\mathrm{O} \cdots \mathrm{H}-\mathrm{N}$ hydrogen bonds forced the backbones to form the designed crescent conformation, whereas intramolecular $\mathrm{N}-\mathrm{H} \cdots \mathrm{F}$ hydrogen bonding formed by the fluorinated benzamide unit would enable the orientation of the iodine atom to the side of the carbonyl $\mathrm{O}$ atom. ${ }^{[7,12]}$ The pyridine $\mathrm{N}$ is a strong halogen-bond acceptor, whereas the I atom on the fluorinated benzene rings is a typical halogen-bond donor. ${ }^{[9]}$

The synthesis of compounds $\mathbf{1}$ and $\mathbf{2}$ are shown in Scheme 2. Compound 7 was first reacted with iodine in the presence of manganese dioxide to afford $\mathbf{8}$ in $91 \%$ yield. ${ }^{[13]}$ The latter was then coupled with Boc-protected hydrazine to produce acyl hydrazine derivative 9 in $77 \%$ yield. Treatment of 9 with hydrochloric acid in ethyl acetate afford acylhydrazine $\mathbf{1 0}$ as a salt in $90 \%$ yield. Compounds $\mathbf{1 0}$ and 11 reacted in refluxed methanol in the presence of pyridine to afford compound 1 in $48 \%$ yield. The coupling reaction of 10 with 12 under similar conditions produced 2 in $31 \%$ yield. For the synthesis of compound 3 (Scheme 3), acid 13 was first reduced with borane to afford 14 in $85 \%$. The

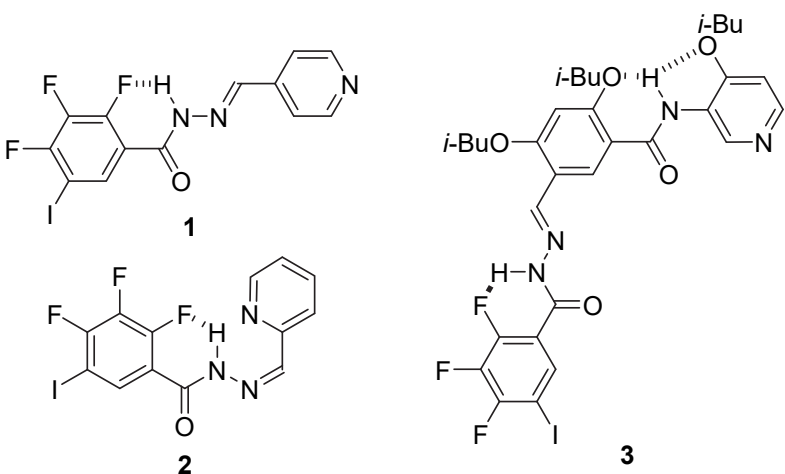

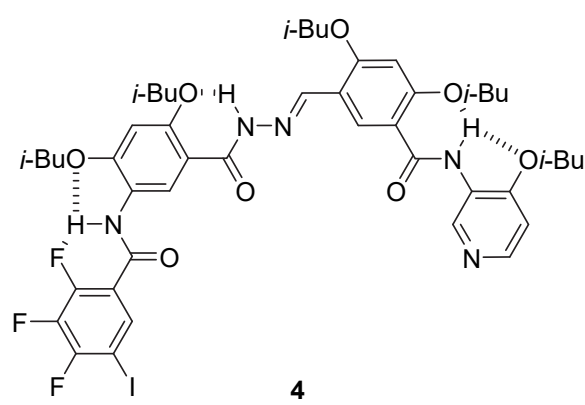

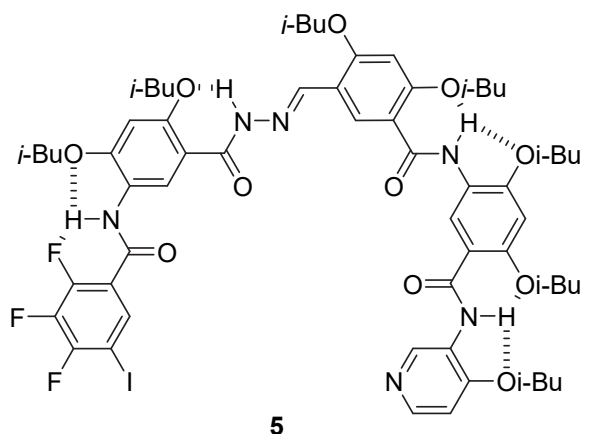

5

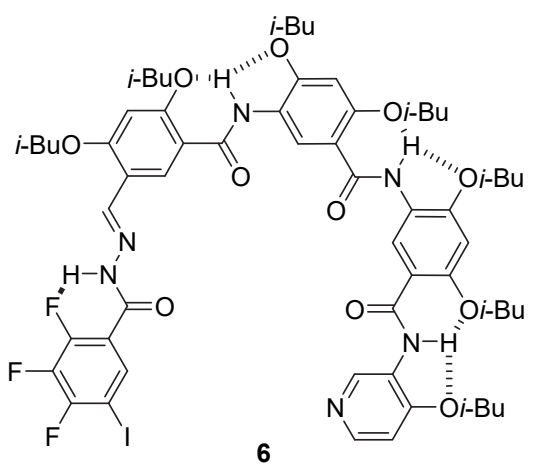

Scheme 1 Structure of compounds $1 \sim 6$

alcohol was then hydrolyzed with lithium hydroxide to acid 15 in $97 \%$ yield. This acid was further treated with acetic anhydride to give $\mathbf{1 6}$ in $85 \%$ yield. The acid was then converted to acyl chloride $\mathbf{1 7}$ and then reacted with 18 to produce 19 in 50\% yield. The ester was then hydrolyzed to alcohol 20 in $91 \%$ yield. The alcohol was further oxidized with manganese dioxide to aldehyde 21 in $90 \%$ yield. Finally, the aldehyde reacted with 10 to afford 3 in 54\% yield. For the synthesis of 4 (Scheme 3), acid 22 was first treated with Boc-protected hydrazine to afford 23 in $82 \%$ yield. 
The nitro derivative was then hydrogenated to 24 in $82 \%$ yield. The aniline intermediate was further coupled with acid 8 to produce $\mathbf{2 5}$ in $93 \%$ yield. Removal of the Boc group with hydrochloric acid in ethyl acetate afforded $\mathbf{2 6}$ in $90 \%$ yield. The acyl hydrazine was further condensed with 21 to form compound 4 in $90 \%$ yield. Using similar approaches, compounds $\mathbf{5}$ and $\mathbf{6}$ were prepared according the routes shown in Scheme 4. Compounds $\mathbf{1} \sim \mathbf{6}$ were insoluble in less polar solvents such as chloroform or dichloromethane, but soluble in polar solvents such as methanol or dimethyl sulfoxide (DMSO). Their ${ }^{1} \mathrm{H}$ NMR spectrum in DMSO- $d_{6}$ revealed that all the compounds existed as two configurational isomers of varying ratio.

The single crystals of compound $\mathbf{1}$ were grown from its<smiles>O=C(O)c1ccc(F)c(F)c1F</smiles>

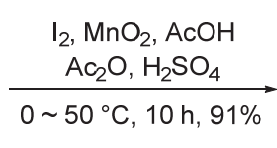

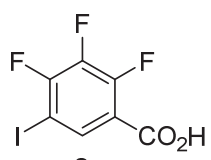

solution in methanol. The crystal structure showed the formation of the expected $\mathrm{F} \cdots \mathrm{H}-\mathrm{N}$ hydrogen bond, with the $\mathrm{F} \cdots \mathrm{H}$ distance $\left(d_{\mathrm{F} \cdots \mathrm{H}}\right)$ being $2.32 \AA$ (Figure 1$)$. The I and $\mathrm{N}$ atoms on the two ends formed strong intermolecular $\mathrm{I} \cdots \mathrm{N}$ halogen bond $\left(d_{\mathrm{I} \cdots \mathrm{N}}=2.87 \AA\right)$, which directed the molecules to self-assemble into extended, zigzag arrays. Between the neighboring linear arrays existed methanol which connected two molecules of 1 through $\mathrm{N}-\mathrm{H} \cdots \mathrm{OMe}\left(d_{\mathrm{H} \cdots \mathrm{O}}=1.91 \AA\right)$ and $\mathrm{O}-\mathrm{H} \cdots \mathrm{O}=\mathrm{C}\left(d_{\mathrm{H} \cdots \mathrm{O}}=2.06 \AA\right)$ hydrogen bonds.

As the isomer of compound 1, 2 was designed to form a stable intramolecular $\mathrm{N}-\mathrm{H} \cdots \mathrm{N}(\mathrm{py})$ hydrogen bond. Single crystals of $\mathbf{2}$ were also grown from its solution in methanol. Most importantly, in the crystal structure this hydrogen bond $\left(d_{\mathrm{H} \cdots \mathrm{N}}=1.97 \AA\right)$ locked the pyridine $\mathrm{N}$ atom and pre-

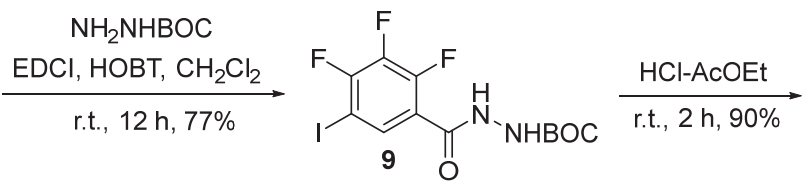<smiles>NNC(=O)c1cc(I)c(F)c(F)c1F</smiles><smiles>O=Cc1ccncc1CCCCCCCO</smiles>

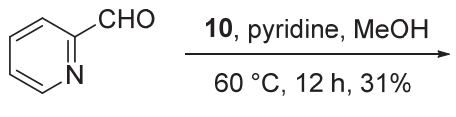

12

Scheme 2 Synthetic routes for compounds 1 and 2
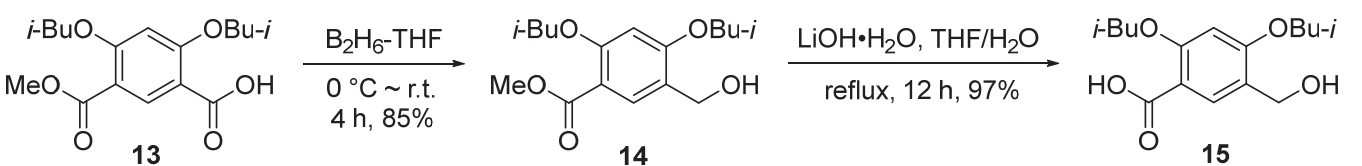

$\frac{(\mathrm{Ac})_{2} \mathrm{O}, \mathrm{DMAP}, \mathrm{NEt}_{3}}{\text { r.t., } 12 \mathrm{~h}, 85 \%}$

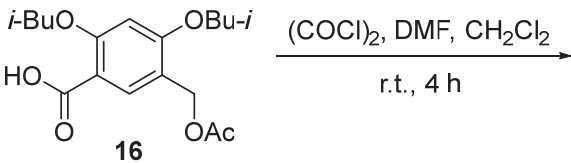<smiles>CCCCOc1cc(OCCC)c(C(=O)Cl)cc1COC(C)=O</smiles>

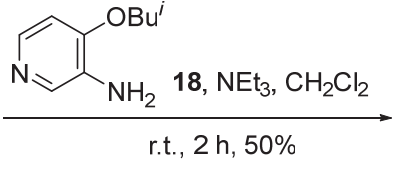
17<smiles>CCCCOc1cc(OCCC)c(C(=O)Nc2cnccc2OCCC)cc1COC(C)=O</smiles>

19

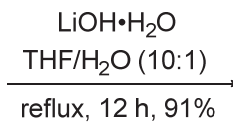<smiles>CCCCOc1cc(OCCC)c(C(=O)Nc2cnccc2OCCC)cc1CO</smiles>

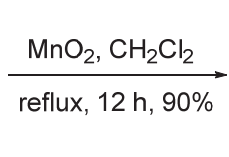

20<smiles>CCCCOc1cc(OCCC)c(C(=O)Nc2cnccc2OCCC)cc1C=O</smiles>

21<smiles>CCCOc1cc(OCCC)c([N+](=O)[O-])cc1C(=O)O</smiles><smiles>CCCCOc1cc(OCCC)c(C(=O)NNC(=O)OCc2ccccc2)cc1NC(=O)c1cc(I)c(F)c(F)c1F</smiles>

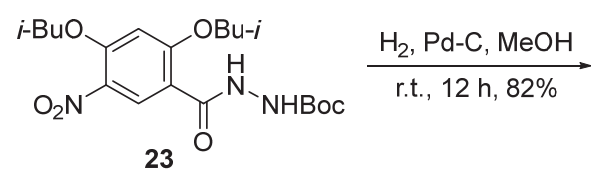
23<smiles>CCCCOc1cc(OCCC)c(N)cc1C(=O)NNC(=O)OCc1ccccc1</smiles>
$24^{\mathrm{O}}$

21, $\mathrm{NEt}_{3}, \mathrm{MeOH}$ reflux, $12 \mathrm{~h}, 90 \%$

Scheme 3 Synthetic routes for compounds 3 and 4 


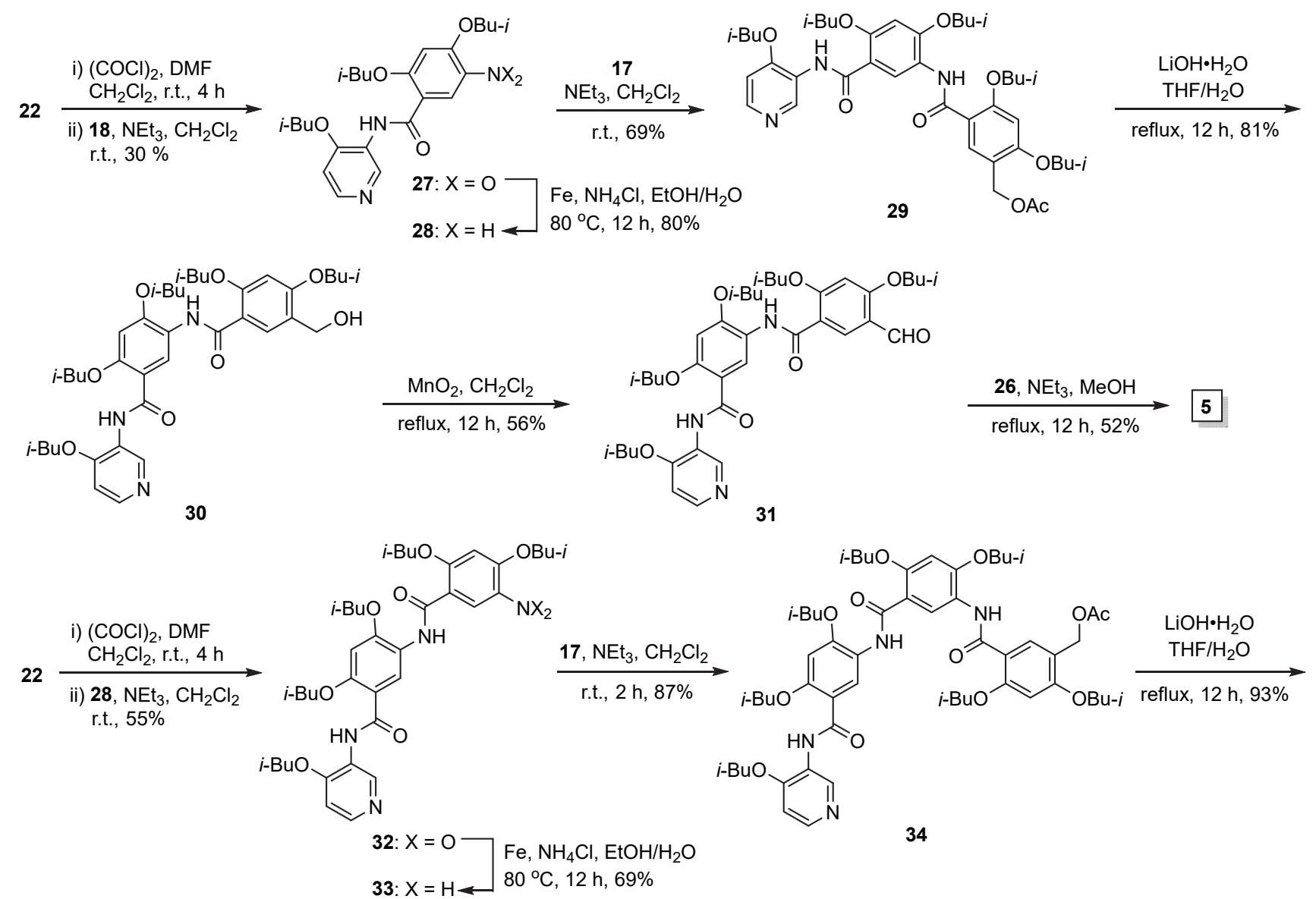<smiles>CCCCOc1cc(OCCC)c(CO)cc1NC(=O)c1cc(NC(=O)c2cc(C(=O)Nc3cnccc3COCC)c(OCCCC)cc2OCCC)c(OCCC)cc1OCCC</smiles><smiles>CCCCOc1cc(OCCC)c(C(=O)Nc2cc(C(=O)Nc3cnccc3OCCC)c(OCCC)cc2OCC(C)C)cc1C(=O)Nc1cc(OCCC)c(OCCC)cc1OCC(C)C</smiles>

Scheme 4 Synthetic routes for compounds 5 and 6

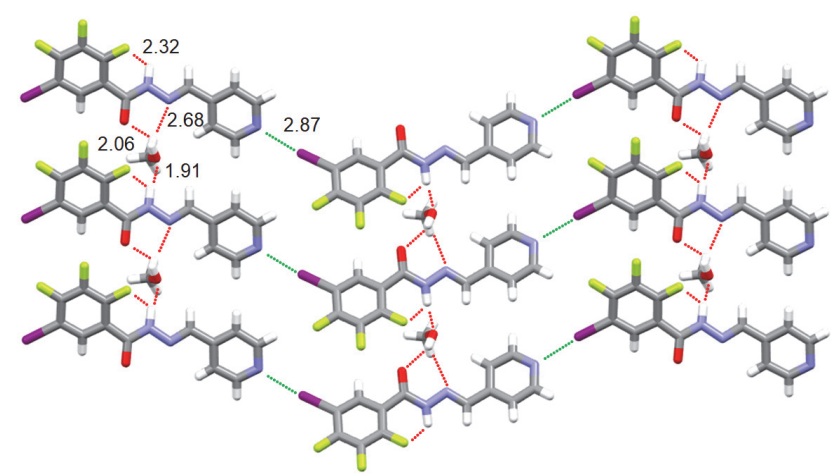

Figure 1 Crystal structure of compound 1

vented it from forming intermolecular $\mathrm{N} \cdots \mathrm{I}$ halogen bond (Figure 2). This $\mathrm{N}-\mathrm{H} \cdots \mathrm{N}($ py) hydrogen bond, together with the intramolecular $\mathrm{F} \cdots \mathrm{H}-\mathrm{N}$ hydrogen bond $\left(d_{\mathrm{F} \cdots \mathrm{H}}=\right.$
$2.11 \AA$ ), forced the backbone to form a folded conformation and the $\mathrm{C}=\mathrm{O}$ and I groups to be located to one side of the folded backbone. As a result, two molecules formed a dimeric structure that was stabilized by two $\mathrm{I} \cdots \mathrm{O}=\mathrm{C}$ halogen bonds $\left(d_{\mathrm{I} \cdots \mathrm{O}}=3.28 \AA\right)$, which suggests a higher stability of the intramolecular $\mathrm{N}-\mathrm{H} \cdots \mathrm{N}($ py) hydrogen bond compared with the intermolecular I $\cdots \mathrm{N}$ halogen bond. Notably, the $\mathrm{F}$ atom at the 3-position of the benzene ring also formed intermolecular $\mathrm{F} \cdots \mathrm{H}-\mathrm{C}$ hydrogen bond $\left(d_{\mathrm{F} \cdots \mathrm{H}}=2.51 \AA\right)$ with the 6-H of the pyridine ring of another neighboring molecule, which led to the formation of another dimeric structure.

Single crystals of compound $\mathbf{3}$ were obtained by evaporating its solution in methanol and dichloromethane $(V$ : $V=1: 1)$. The crystal structure of this trimeric molecule revealed the existence of two intramolecular $\mathrm{N}-\mathrm{H} \cdots \mathrm{O}$ 


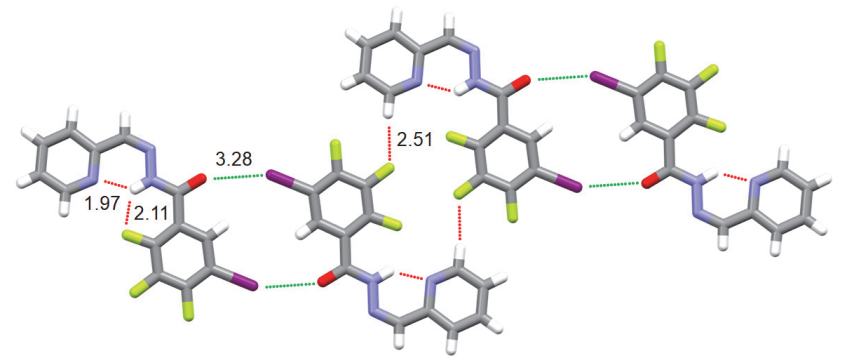

Figure 2 Crystal structure of compound 2

hydrogen bonds $\left(d_{\mathrm{O}} \cdots \mathrm{H}=2.03\right.$ and $\left.2.32 \AA\right)$ and one intramolecular $\mathrm{N}-\mathrm{H} \cdots \mathrm{F}$ hydrogen bond $\left(d_{\mathrm{F} \cdots \mathrm{H}}=2.21 \AA\right.$ ) (Figure 3). The $\mathrm{C}=\mathrm{N}$ bond of the hydrazone unit existed in the trans-configuration and the $\mathrm{N}=\mathrm{CH}$ proton of the hydrazone unit was involved in intramolecular $\mathrm{C}-\mathrm{H} \cdots \mathrm{O}$ hydrogen bond $\left(d_{\mathrm{O} \cdots \mathrm{H}}=2.48 \AA\right)$ with the adjacent butoxy $\mathrm{O}$ atom. All these intramolecular interactions combined to induce the whole backbone to exhibit a planar, crescent conformation, with the iodine and pyridine $\mathrm{N}$ atoms pointing to the identical direction nearly parallelly. As a result, two molecules formed a supramolecular macrocycle through two intermolecular two strong $\mathrm{I} \cdots \mathrm{N}$ halogen bonds $\left(d_{\mathrm{I} \cdots \mathrm{N}}=2.83 \AA\right)$, which should enhance each other with a positive cooperativity. The cavity of the dimeric macrocycle entrapped two methanol molecules and each methanol molecule formed one strong $\mathrm{OH} \cdots \mathrm{O}=\mathrm{C}$ hydrogen bond $\left(d_{\mathrm{H} \cdots \mathrm{O}}=2.01 \AA\right)$ and one $(\mathrm{Me}) \mathrm{C}-\mathrm{H} \cdots \mathrm{O}=\mathrm{C}$ hydrogen bond $\left(d_{\mathrm{H} \cdots \mathrm{O}}=2.62 \AA\right)$ with the two carbonyl $\mathrm{O}$ atoms of one crescent molecule. These two hydrogen bonds should also play a role in stabilizing the crescent conformation of $\mathbf{3}$. In addition to the above intra- and inter-molecular hydrogen and halogen bonds, the pyridine unit of one molecule also formed two very weak intermolecular (py) $\mathrm{C}-\mathrm{H} \cdots \mathrm{F}$ hydrogen bonds $\left(d_{\mathrm{F} \cdots \mathrm{H}}=2.66\right.$ and $\left.2.67 \AA\right)$ with two $\mathrm{F}$ atoms of another molecule, through which the dimeric macrocycles selfassembled into planar supramolecular arrays. The $\mathrm{CH}_{3}$ protons of the side iso-butyl chain also formed weak $\mathrm{C}-\mathrm{H} \cdots \mathrm{F}$ and $\mathrm{C}-\mathrm{H} \cdots \mathrm{Cl}$ hydrogen bonds with the $\mathrm{F}$ atom of another molecule or the entrapped dichloromethane. One $\mathrm{CH}$ proton of the entrapped dichloromethane was also hydrogen bonded to the fluorinated benzamide $\mathrm{O}$ atom. All these hydrogen bonds combined to stabilize the stacking of the above supramolecular macrocycle arrays.

Single crystals of the longer tetrameric compound $\mathbf{4}$ were grown from the solution of methanol and dichloromethane $(3: 1)$ containing $1 \%$ of water. Its crystal structure revealed a more curved, crescent conformation which was stabilized by the designed intramolecular interactions, including four $\mathrm{N}-\mathrm{H} \cdots \mathrm{O}$, one $\mathrm{N}-\mathrm{H} \cdots \mathrm{F}$ and one $\mathrm{C}-\mathrm{H} \cdots \mathrm{O}$ hydrogen bond (Figure 4a). Although the compound bears five iso-butoxy side chains, the backbone did not undergo large distortion. The appended iodobenzene and pyridine rings had a spatial angle of approximately $44^{\circ}$ for their ideal halogen bonding directions, which did not favor the formation of dimeric macrocycle. Instead, the I atom of one molecular and the pyridine $\mathrm{N}$ atom of another molecule

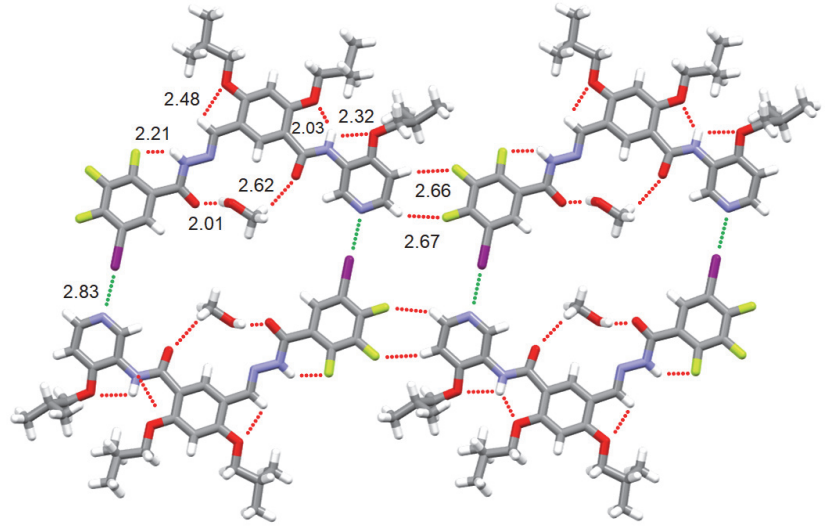

Figure 3 Crystal structure of compound $\mathbf{3}$

were engaged in $\mathrm{I} \cdots \mathrm{O}$ halogen bond $\left(d_{\mathrm{I} \cdots \mathrm{O}}=3.22 \AA\right)$ and weak $\mathrm{N} \cdots \mathrm{O}$ contact $\left(d_{\mathrm{N} \cdots \mathrm{O}}=3.04 \AA\right)$, respectively, with the $\mathrm{O}$ atom of one water molecule. This rare $\mathrm{N} \cdots \mathrm{O}$ contact may be attributed to the existence of a $\sigma$-hole by the $\mathrm{N}$ atom, ${ }^{[14]}$ but may also be caused by the close stacking the folded molecules. Probably due to the existence of different orientations, the protons of the water solvent were not resolved.
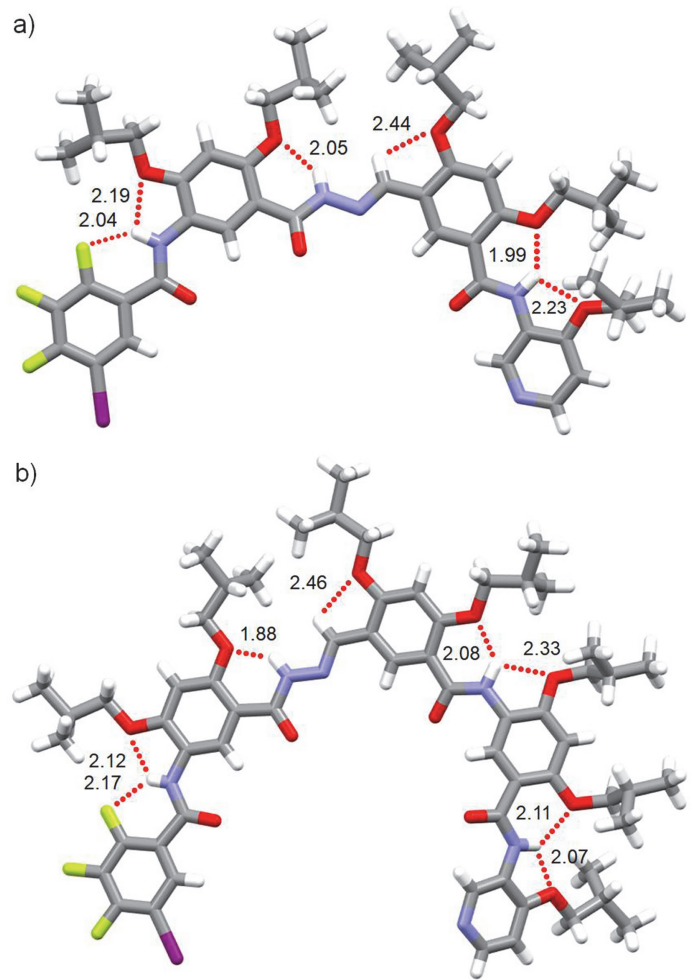

Figure 4 Crystal structure of compounds of (a) 4 and (b) 5

By evaporating the solution of compound 5 in methanol and dichloromethane $(V: V=5: 1)$, we obtained single crystals of this pentameric foldamer. As expected, the compound formed totally eight intramolecular hydrogen bonds (Figure 4b), which included six $\mathrm{N}-\mathrm{H} \cdots \mathrm{O}$, one $\mathrm{N}-\mathrm{H} \cdots \mathrm{F}$ and one $\mathrm{C}-\mathrm{H} \cdots \mathrm{O}$ hydrogen bond. The two amide units on the pyridine side were twisted considerably from the plane defined by the other part of the backbone, 
which was roughly planar. The longer backbone caused the appended iodobenzene and pyridine rings to form a spatial angle of approximately $86^{\circ}$ for their ideal halogen bonding directions. The I atom formed a strong I $\cdots \mathrm{O}$ halogen bond with the entrapped methanol. Probably due to that the methanol molecule adopted two different spatial orientation, ${ }^{[15]}$ this halogen bonding existed in two different patterns $\left(d_{\mathrm{I} \cdots \mathrm{O}}=3.33\right.$ and $\left.3.37 \AA\right)$. The $\mathrm{N}$ atom of the pyridine ring on the other end also formed $\mathrm{N} \cdots \mathrm{O}$ interaction $\left(d_{\mathrm{N} \cdots \mathrm{O}}=\right.$ $2.79 \AA$ ) with the methanol $\mathrm{O}$ atom. Connected by the disordered methanol molecules, this crescent compound gave rise to a unique alternately arranged, S-styled supramolecular helix, and the adjacent helices further stacked alternately to afford extended double helix arrays.

Compound $\mathbf{6}$ was the isomer of pentamer $\mathbf{5}$, with the hydrazine unit being introduced to connect the fluorinate benzene ring. Its crystal structure also displayed all the eight different kinds of hydrogen bonds as revealed for $\mathbf{5}$. However, the benzene ring in the middle was distorted remarkably from the two connected dimeric aromatic segments. Moreover, this compound did not form intermolecular I...O halogen bonds. Instead, the I atom was engaged in a halogen bond $\left(d_{\mathrm{I} \cdots \mathrm{O}=\mathrm{C}}=2.92 \AA\right)$ with the $\mathrm{O}$ atom of the amide on the pyridine ring of another molecule, which induced the compound to give rise to a supramolecular helix (Figure 5). The aromatic dimer on the pyridine side stacked with the counterpart of another molecule in an antiparallel manner, whereas the pyridine $\mathrm{N}$ atom formed a weak $\mathrm{N} \cdots \mathrm{H}-\mathrm{C}$ hydrogen bond $\left(d_{\mathrm{N} \cdots \mathrm{H}}=2.72 \AA\right)$ with one $\mathrm{CH}_{2}$ unit of another molecule. These weak interactions combined to induce two adjacent supramolecular helices to produce a new antiparallel supramolecular double helix.

a)
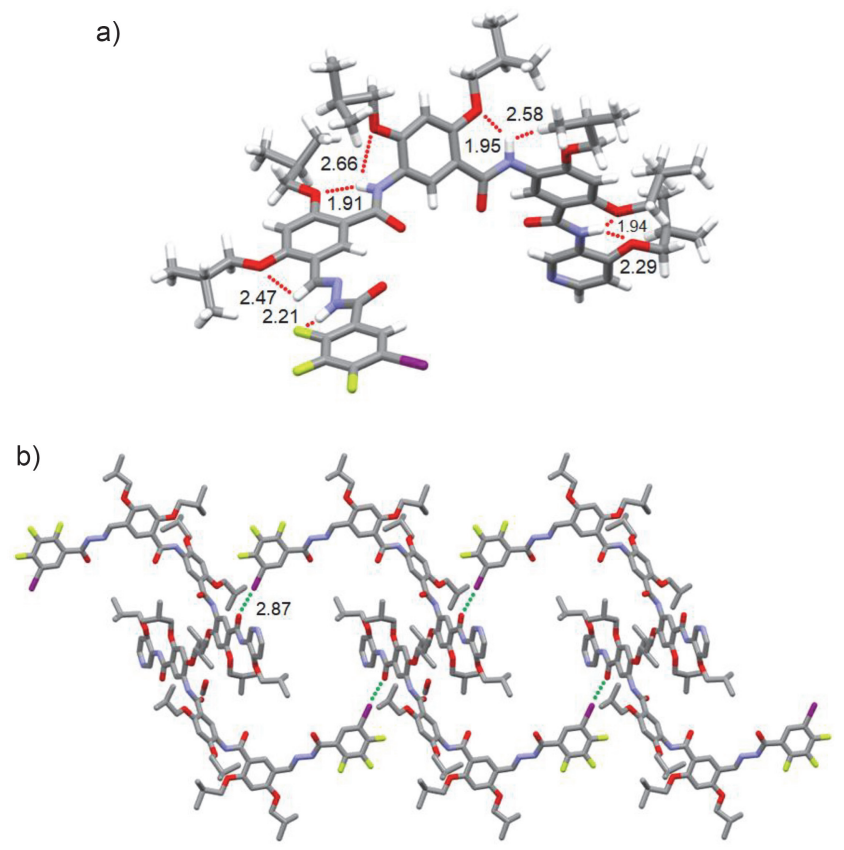

Figure 5 Crystal structure of compound 6 (a) Structure showing the intramolecular hydrogen bonds, and (b) Structure of the formed supramolecular double helix stabilized by intermolecular halogen bonding and aromatic stacking

\section{Conclusions}

We have demonstrated that intermolecular halogen bonding plays an important role in controlling the aggregation of linear hydrogen bonded aromatic amides in crystals. The crystal structure of the studied six compounds exhibits different halogen bonding pattern, which reflects the complexity caused by the competitiveness of different nonvalent interactions in the solid state. For all the six compounds, the iodine atom acts as acceptor to form halogen bonding. However, although pyridine $\mathrm{N}$ atom has been well-established as good halogen bonding acceptor, it appears that the $\mathrm{O}$ atom of polar solvents like methanol or the amide unit of the substrates is comparable in functioning as competitive acceptor. Given this observation, careful choice of a solvent may present a useful approach in modulating the self-assembly of advanced supramolecular architectures in the solid state. To realize this aim, the shape and size of the solvent should be considered to avoid the disordering of small solvents. This study also reveals that, when the halogen bonding donor and acceptor on the same side of the backbone are arranged parallelly, stable dimeric macrocycles can be formed. In the future, we will utilize this character to design tubular architectures by introducing additional functional groups to enhance their stacking.

\section{Experimental section}

\subsection{General methods}

All reagents were obtained from commercial suppliers and used without further purification unless otherwise noted. All reactions were carried out under the atmosphere of $\mathrm{N}_{2}$. ${ }^{1} \mathrm{H}$ NMR and ${ }^{13} \mathrm{C}$ NMR spectra were recorded on a Bruker AVANCE III with a $400 \mathrm{MHz}$ spectrometer in the indicated solvents at $25^{\circ} \mathrm{C}$. Chemical shifts are expressed using residual proton resonances of the deuterated solvents as the internal standards. ${ }^{19} \mathrm{~F}$ NMR spectra were recorded on $300 \mathrm{MHz}$ spectrometer in the indicated solvents. The crystals were measured using a Bruker D8 Venture-Metaljet diffractometer equipped with a PHOTON II area detector and HELIOS multilayer optics monochrommated $\mathrm{Cu}-\mathrm{K} \alpha$ and Mo-K $\alpha$ radiation (lambda $=1.54184$ and $0.71073 \AA$ ). The crystal structures were solved by direct method and refined by full-matrix least-squares methods based on an F2 using SHELXL-2014 software. The Crystals of $\mathbf{1} \sim \mathbf{3}$ were grown by evaporating their solution in $\mathrm{MeOH}$, and the crystals of $\mathbf{4}$ and $\mathbf{5}$ were grown from $\mathrm{CH}_{2} \mathrm{Cl}_{2} / \mathrm{MeOH}$ $(V: V=3: 1)$ and $\mathrm{CH}_{2} \mathrm{Cl}_{2} / \mathrm{MeOH}(V: V=5: 1)$ respectively and the crystal of $\mathbf{6}$ was grown from $\mathrm{CH}_{2} \mathrm{Cl}_{2} / \mathrm{MeOH} /$ EtOAc $(V: V: V=3: 1: 1)$. Compounds $\mathbf{8}^{[13]}$ and $\mathbf{2 2}^{[11 \mathrm{~b}]}$ were prepared according to the reported method. ${ }^{[1,2]}$ The crystal data of compounds $1 \sim \mathbf{6}$ have been deposited in Cambridge Crystallographic Data Centre (CCDC deposit Nos. 2058399- 2058402, 2058404 and 2058405).

\subsection{Synthesis of compound 9}

To a solution of compound $\mathbf{8}^{[1]}(0.40 \mathrm{~g}, 1.3 \mathrm{mmol})$ in 
dichloromethane $(40 \mathrm{~mL})$ were added compound tert-butyl carbanate $(0.26 \mathrm{~g}, 1.98 \mathrm{mmol})$, EDCI $(0.50 \mathrm{~g}, 2.64 \mathrm{mmol})$ and HOBT $(0.35 \mathrm{~g}, 2.64 \mathrm{mmol})$. The mixture was stirred at room temperature for $12 \mathrm{~h}$ and then quenched by water (40 $\mathrm{mL}$ ). The organic layer was separated and the aqueous layer was extracted with dichloromethane $(40 \mathrm{~mL} \times 3)$. The organic phases were combined and washed with water $(50$ $\mathrm{mL} \times 3)$ and saturated brine $(50 \mathrm{~mL})$ and dried over with $\mathrm{Na}_{2} \mathrm{SO}_{4}$. The solvent was then evaporated, after dried in vacuo, to afford tert-butyl 2-(2,3,4-trifluoro-5-iodobenzoyl)hydrazine-1-carboxylate (9) as a white solid (0.42 g, 77\%). m.p. $153.9 \sim 154.3{ }^{\circ} \mathrm{C} ;{ }^{1} \mathrm{H}$ NMR (400 MHz, $\mathrm{CDCl}_{3}$ ) $\delta: 8.28 \sim 8.32(\mathrm{~m}, 1 \mathrm{H}), 8.15(\mathrm{~s}, 1 \mathrm{H}), 6.71(\mathrm{~s}, 1 \mathrm{H}), 1.50(\mathrm{~s}$, $12 \mathrm{H}) ;{ }^{13} \mathrm{C} \mathrm{NMR}\left(100 \mathrm{MHz}, \mathrm{CDCl}_{3}\right) \delta: 160.2,155.0,154.8$, $152.3,152.2,151.3,151.2,148.8,148.7,140.7,138.2$, 138.0, 137.8, 134.5, 126.8, 126.2, 117.7, 117.4, 111.1, 82.5, 28.1; ${ }^{19} \mathrm{~F}$ NMR $\left(300 \mathrm{MHz}, \mathrm{CDCl}_{3}\right) \delta:-104.55 \sim-104.65$ $(\mathrm{m}, 1 \mathrm{~F}),-131.63 \sim-131.68(\mathrm{~m}, 1 \mathrm{~F}),-154.13 \sim-$ 154.19 (m, 1F). HRMS (ESI) calcd for $\mathrm{C}_{12} \mathrm{H}_{12} \mathrm{~F}_{3} \mathrm{IN}_{2} \mathrm{NaO}_{3}$ $[\mathrm{M}+\mathrm{Na}]^{+}:$438.9742. found 438.9747 .

\subsection{Synthesis of compound 10}

To a $50 \mathrm{~mL}$ round-bottom flask were added compound 9 $(0.21 \mathrm{~g}, 0.50 \mathrm{mmol})$ and saturated $\mathrm{HCl}-\mathrm{AcOEt}(4 \mathrm{~mL})$. The solution was stirred at room temperature for $2 \mathrm{~h}$. Then the solid was filtrated and washed by hexane $(10 \mathrm{~mL})$ for three times to afford 2,3,4-trifluoro-5-iodo- $N$ '-(pyridin-4-ylmethylene)benzohydrazide (10) as a white solid (70 $\mathrm{mg}, 44 \%$ ). m.p. $244.6 \sim 245.0{ }^{\circ} \mathrm{C} ;{ }^{1} \mathrm{H}$ NMR $\left(400 \mathrm{MHz}, \mathrm{CDCl}_{3}\right) \delta$ : $7.91 \sim 7.95(\mathrm{~m}, 1 \mathrm{H}) ;{ }^{13} \mathrm{C} \mathrm{NMR}\left(100 \mathrm{MHz}, \mathrm{CDCl}_{3}\right) \delta: 162.9$, $160.8,154.2,154.1,151.7,151.6,150.7,150.6,148.1$, $148.8,140.7,140.5,138.3,138.1,138.0,132.9,132.8$, $119.9,119.8 ;{ }^{19} \mathrm{~F}$ NMR $\left(300 \mathrm{MHz}, \mathrm{CDCl}_{3}\right) \delta:-108.85 \sim$ $-108.91(\mathrm{~m}, 1 \mathrm{~F}),-133.54 \sim-133.64(\mathrm{~m}, 1 \mathrm{~F}),-$ $155.66 \sim-155.78(\mathrm{~m}, 1 \mathrm{~F})$. HRMS (ESI) calcd for $\mathrm{C}_{7} \mathrm{H}_{5} \mathrm{~F}_{3} \mathrm{IN}_{2} \mathrm{O}[\mathrm{M}+\mathrm{H}]^{+}: 316.9399$. found 316.9399 .

\subsection{Synthesis of compound 1}

To a solution of compound $\mathbf{1 0}(0.10 \mathrm{~g}, 0.28 \mathrm{mmol})$ in $\mathrm{MeOH}(5 \mathrm{~mL})$ and pyridine $(0.2 \mathrm{~mL})$ was added 4-aldehyde pyridine 11 (30 mg, $0.28 \mathrm{mmol})$. The mixture was stirred at $60{ }^{\circ} \mathrm{C}$ for $12 \mathrm{~h}$ and cooled to room temperature. The precipitation formed was filtrated and washed with dichloromethane to afford, after dried in vacuo, (E)-2,3,4-trifluoro5-iodo- $N$ '-(pyridin-4-ylmethylene)benzohydrazide (1) as a white solid (55 mg, 48\%), which existed as two configurational isomers with a $1: 0.71$ as evidenced by the ${ }^{1} \mathrm{H}$ NMR. m.p. $230.1 \sim 210.7{ }^{\circ} \mathrm{C} ;{ }^{1} \mathrm{H}$ NMR $(400 \mathrm{MHz}$, DMSO- $d_{6}$, major) $\delta$ : $12.35(\mathrm{~s}, 1 \mathrm{H}), 8.68(\mathrm{~d}, J=4 \mathrm{~Hz}, 2 \mathrm{H})$, $8.33(\mathrm{~s}, 1 \mathrm{H}), 8.01 \sim 8.09(\mathrm{~m}, 1 \mathrm{H}), 7.69(\mathrm{~d}, J=4 \mathrm{~Hz}, 2 \mathrm{H}) ;{ }^{19} \mathrm{~F}$ NMR (300 MHz, DMSO- $d_{6}$, major) $\delta:-110.08 \sim-$ $110.46(\mathrm{~m}, 1 \mathrm{~F}),-134.55 \sim-134.66(\mathrm{~m}, 1 \mathrm{~F}),-155.97 \sim$ $-156.10(\mathrm{~m}, 1 \mathrm{~F}) ;{ }^{1} \mathrm{H}$ NMR (400 MHz, DMSO- $d_{6}$, minor) $\delta$ : $12.35(\mathrm{~s}, 1 \mathrm{H}), 8.58(\mathrm{~d}, J=2 \mathrm{~Hz}, 1 \mathrm{H}), 8.09(\mathrm{~s}, 1 \mathrm{H}), 7.87 \sim$ $7.90(\mathrm{~m}, 1 \mathrm{H}), 7.41$ (d, $J=2 \mathrm{~Hz}, 1 \mathrm{H}) ;{ }^{19} \mathrm{~F}$ NMR $(300 \mathrm{MHz}$, DMSO- $d_{6}$, minor) $\delta$ : $-111.46 \sim-111.56(\mathrm{~m}, 1 \mathrm{~F})$, $132.72 \sim-132.83(\mathrm{~m}, 1 \mathrm{~F}),-156.80 \sim-156.92(\mathrm{~m}, 1 \mathrm{~F})$; ${ }^{13} \mathrm{C}$ NMR (100 MHz, DMSO- $\left.d_{6}\right) \delta: 164.7,158.3,153.6$,
$153.1,151.1,151.0,150.8,150.4,150.3,147.9,147.8$, $147.1,146.8,143.3,141.5,141.3,140.5,140.4,140.2$, $138.0,137.8,132.9,132.6,123.3,123.2,122.6,122.5$, 121.6, 121.2, 78.8, 78.5, 78.4, 78.2. HRMS (ESI) calcd for $\mathrm{C}_{13} \mathrm{H}_{8} \mathrm{~F}_{3} \mathrm{IN}_{3} \mathrm{O}[\mathrm{M}+\mathrm{H}]^{+}:$405.9664. found 405.9667.

\subsection{Synthesis of compound 2}

To a solution of compound $\mathbf{1 0}(0.10 \mathrm{~g}, 0.28 \mathrm{mmol})$ in $\mathrm{MeOH}(5 \mathrm{~mL})$ and pyridine $(0.2 \mathrm{~mL})$ was added 2-aldehyde pyridine 12 (30 mg, $0.28 \mathrm{mmol})$. The mixture was stirred at $60{ }^{\circ} \mathrm{C}$. After workup as described for compound 1, 2,3,4-trifluoro-5-iodo- $N$ '-(pyridin-2-ylmethylene)benzohydrazide (2) was obtained as a white solid (31\%), which existed as two configurational isomers. m.p. $233.0 \sim 233.7{ }^{\circ} \mathrm{C} ;{ }^{1} \mathrm{H}$ NMR (400 MHz, DMSO- $d_{6}$, major) $\delta: 12.32(\mathrm{~s}, 1 \mathrm{H}), 8.67 \sim$ $8.68(\mathrm{~m}, 1 \mathrm{H}), 8.40(\mathrm{~s}, 1 \mathrm{H}), 7.99 \sim 8.05(\mathrm{~m}, 2 \mathrm{H}), 7.85 \sim 7.89$ $(\mathrm{m}, 1 \mathrm{H}), 7.52 \sim 7.55(\mathrm{~m}, 1 \mathrm{H}) ;{ }^{19} \mathrm{~F}$ NMR $(300 \mathrm{MHz}, \mathrm{DMSO}-$ $d_{6}$, major) $\delta:-109.94 \sim-110.04(\mathrm{~m}, 1 \mathrm{~F}),-134.60 \sim-$ $134.71(\mathrm{~m}, 1 \mathrm{~F}),-156.78 \sim-156.90(\mathrm{~m}, 1 \mathrm{~F}) ;{ }^{1} \mathrm{H}$ NMR (400 MHz, DMSO- $d_{6}$, minor) $\delta: 12.47(\mathrm{~s}, 1 \mathrm{H}), 8.60 \sim 8.61$ $(\mathrm{m}, 1 \mathrm{H}), 8.17(\mathrm{~s}, 1 \mathrm{H}), 7.99 \sim 8.05(\mathrm{~m}, 2 \mathrm{H}), 7.57 \sim 7.59(\mathrm{~m}$, 1H), $7.43 \sim 7.47(\mathrm{~m}, 1 \mathrm{H}) ;{ }^{19} \mathrm{~F}$ NMR $\left(300 \mathrm{MHz}, \mathrm{DMSO}-d_{6}\right.$, minor) $\delta:-111.38 \sim-111.49(\mathrm{~m}, 1 \mathrm{~F}),-132.63 \sim-$ $132.74(\mathrm{~m}, 1 \mathrm{~F}),-155.91 \sim-155.03(\mathrm{~m}, 1 \mathrm{~F}) ;{ }^{13} \mathrm{C} \mathrm{NMR}$ $\left(100 \mathrm{MHz}, \mathrm{DMSO}-d_{6}\right) \delta: 164.7,158.5,151.0,147.6,146.4$, $143.3,140.7,140.3,132.9,132.6,126.1,125.7,122.2$, 121.0, 79.0, 78.7. HRMS (ESI) calcd for $\mathrm{C}_{13} \mathrm{H}_{8} \mathrm{~F}_{3} \mathrm{IN}_{3} \mathrm{O}[\mathrm{M}$ $+\mathrm{H}]^{+}:$405.9664, found 405.9669.

\subsection{Synthesis of compound 14}

To a solution of compound $\mathbf{1 3}(0.65 \mathrm{~g}, 2.0 \mathrm{mmol})$ in dry THF $(10 \mathrm{~mL})$ was slowly added a solution of borane in THF $\left(10 \mathrm{~mL}, 1 \mathrm{~mol} \cdot \mathrm{L}^{-1}, 10 \mathrm{mmol}\right)$ at $0{ }^{\circ} \mathrm{C}$. The solution was then at room temperature for $4 \mathrm{~h}$ and quenched by cold water (10 $\mathrm{mL})$. The organic layer was separated and the aqueous layer extracted with dichloromethane $(10 \mathrm{~mL} \times 3)$. The organic phases were combined and washed with water $(10 \mathrm{~mL} \times 3)$ and brine $(15 \mathrm{~mL})$ and dried over sodium sulfate. After removal of the solvent with a rotavapor, the crude product obtained was subjected to column chromatography ( $n$ hexane/AcOEt, $V: V=6: 1$ ) to afford methyl 5-(hydroxymethyl)-2,4-diisobutoxybenzoate (14) as colorless oil $(0.53$ g, 85\%). ${ }^{1} \mathrm{H}$ NMR (400 MHz, $\left.\mathrm{CDCl}_{3}\right) \delta: 7.83(\mathrm{~s}, 1 \mathrm{H}), 6.41$ $(\mathrm{s}, 1 \mathrm{H}), 4.64(\mathrm{~s}, 2 \mathrm{H}), 3.86(\mathrm{~s}, 2 \mathrm{H}), 3.79 \sim 3.83(\mathrm{~m}, 4 \mathrm{H})$, $2.13 \sim 2.23(\mathrm{~m}, 2 \mathrm{H}), 1.07 \sim 1.10(\mathrm{~m}, 12 \mathrm{H}) ;{ }^{13} \mathrm{C}$ NMR $(100$ $\left.\mathrm{MHz}, \mathrm{CDCl}_{3}\right) \delta: 166.3,161.3,161.0,132.8,121.1,111.5$, 97.0, 75.6, 74.6, 61.2, 51.6, 28.5, 28.3, 19.3, 19.2. HRMS (ESI) calcd for $\mathrm{C}_{17} \mathrm{H}_{26} \mathrm{NaO}_{5}[\mathrm{M}+\mathrm{Na}]^{+}: 333.1678$, found 333.1672 .

\subsection{Synthesis of compound 15}

To a solution of compound $\mathbf{1 4}(0.56 \mathrm{~g}, 1.8 \mathrm{mmol})$ in THF $(10 \mathrm{~mL})$ and $\mathrm{H}_{2} \mathrm{O}(1 \mathrm{~mL})$ was added $\mathrm{LiOH} \cdot \mathrm{H}_{2} \mathrm{O}(0.15 \mathrm{~g}, 3.6$ $\mathrm{mmol})$. The mixture was stirred under reflux for $12 \mathrm{~h}$ and then cooled to room temperature. To the solution was added water $(10 \mathrm{~mL})$ and hydrochloric acid $\left(1 \mathrm{~mol} \cdot \mathrm{L}^{-1}\right)$ was added to $\mathrm{pH}=2$. The aqueous solution was extracted with dichloromethane $(10 \mathrm{~mL} \times 3)$. The organic phases were 
combined and washed with water $(10 \mathrm{~mL} \times 3)$ and brine $(10 \mathrm{~mL})$ and dried over sodium sulfate. After the solvent was removed and dryness in vacuo, 5-(hydroxymethyl)-2,4diisobutoxybenzoic acid (15) was obtained as white solid (0.52 g, 97\%). m.p. 131.5 131.9 ${ }^{\circ} \mathrm{C} ;{ }^{1} \mathrm{H}$ NMR (400 MHz, $\left.\mathrm{CDCl}_{3}\right) \delta: 8.13(\mathrm{~s}, 1 \mathrm{H}), 6.48(\mathrm{~s}, 1 \mathrm{H}), 4.69(\mathrm{~s}, 2 \mathrm{H}), 4.04(\mathrm{~d}$, $J=2 \mathrm{~Hz}, 2 \mathrm{H}), 3.86(\mathrm{~d}, J=2 \mathrm{~Hz}, 2 \mathrm{H}), 2.17 \sim 2.30$ (m, 2H), $1.10 \sim 1.15(\mathrm{~m}, 12 \mathrm{H}) ;{ }^{13} \mathrm{C} \mathrm{NMR}\left(100 \mathrm{MHz}, \mathrm{CDCl}_{3}\right) \delta$ : $165.3,162.2,159.1,133.7,123.6,109.3,96.1,76.7,75.0$, $60.8,28.3,28.2,19.3,19.2$. HRMS (ESI) calcd for $\mathrm{C}_{16} \mathrm{H}_{23} \mathrm{O}_{5}$ $[\mathrm{M}-\mathrm{H}]^{-}: 295.1545$, found 295.1541 .

\subsection{Synthesis of compound 16}

To a solution of compound $\mathbf{1 5}(99 \mathrm{mg}, 0.33 \mathrm{mmol})$ in dichloromethane $(10 \mathrm{~mL})$ were added triethylamine $(0.10$ $\mathrm{mL}, 0.73 \mathrm{mmol}$ ), $N, N$-dimethylpyridine (DMAP , $8 \mathrm{mg}$, $0.066 \mathrm{mmol})$ and acetic anhydride $(0.038 \mathrm{~mL}, 0.40 \mathrm{mmol})$. The mixture was stirred at room temperature for 12 hour and then washed with $\mathrm{HCl}$ aqueous solution $\left(1 \mathrm{~mol} \bullet \mathrm{L}^{-1}, 2\right.$ $\mathrm{mL} \times 3)$, water $(4 \mathrm{~mL})$ and brine $(4 \mathrm{~mL})$ and dried over sodium sulfate. After removal of the solvent under reduced pressure, 5-(acetoxymethyl)-2,4-diisobutoxybenzoic acid (16) was obtained as a white solid (95 mg, 85\%). m.p. 136.2 $136.8{ }^{\circ} \mathrm{C} ;{ }^{1} \mathrm{H}$ NMR (400 MHz, $\left.\mathrm{CDCl}_{3}\right) \delta: 8.16(\mathrm{~s}$, $1 \mathrm{H}), 6.47(\mathrm{~s}, 1 \mathrm{H}), 5.12(\mathrm{~s}, 2 \mathrm{H}), 4.04(\mathrm{~d}, J=2 \mathrm{~Hz}, 2 \mathrm{H})$, $3.83(\mathrm{~d}, J=2 \mathrm{~Hz}, 2 \mathrm{H}), 2.14 \sim 2.30(\mathrm{~m}, 2 \mathrm{H}), 2.12(\mathrm{~s}, 3 \mathrm{H})$, $1.13(\mathrm{~d}, J=2 \mathrm{~Hz}, 6 \mathrm{H}), 1.08$ (d, $J=2 \mathrm{~Hz}, 6 \mathrm{H}) ;{ }^{13} \mathrm{C}$ NMR $(100$ $\left.\mathrm{MHz}, \mathrm{CDCl}_{3}\right) \delta: 170.8,165.1,162.4,159.5,135.0,118.7$, 109.4, 96.0, 75.0, 61.0, 28.3, 28.2, 19.2, 19.1. HRMS (ESI) calcd for $\mathrm{C}_{18} \mathrm{H}_{25} \mathrm{O}_{6}[\mathrm{M}-\mathrm{H}]^{-}: 337.1651$, found 337.1649 .

\subsection{Synthesis of compound 19}

To a solution of compound $16(0.20 \mathrm{~g}, 0.59 \mathrm{mmol})$ in dry dichloromethane $(5 \mathrm{~mL})$ was added $(\mathrm{COCl})_{2}(0.6 \mathrm{~mL}, 5.9$ $\mathrm{mmol})$ and dry DMF $(0.05 \mathrm{~mL})$. The mixture was stirred at room temperature for $4 \mathrm{~h}$ and then evaporated under reduced pressure to afford acyl chloride 17, which was further dissolved in dry dichloromethane $(3.0 \mathrm{~mL})$. To the solution, cooled in an ice-bath, were added a solution of compound $18(98 \mathrm{mg}, 0.59 \mathrm{mmol})$ and triethylamine $(73 \mathrm{mg}, 0.72$ $\mathrm{mmol})$ in dry dichloromethane $(5.0 \mathrm{~mL})$. The solution was stirred at room temperature for $2 \mathrm{~h}$ and then water $(10.0 \mathrm{~mL})$ was added. The organic layer was separated and the aqueous layer was extracted with dichloromethane $(10 \mathrm{~mL} \times 3)$. The organic phases were combined and washed with water $(10 \mathrm{~mL} \times 3)$ and dried over sodium sulfate. The solvent was then removed with a rotavapor and the resulting residue subjected to column chromatography (dichloromethane/ methanol, $V: V=20: 1)$ to afford 2,4-diisobutoxy-5-((4isobutoxypyridin-3-yl)carbamoyl)benzyl acetate (19) as a white solid (0.15 g, 50\%). m.p. 143.1 143.6 ${ }^{\circ} \mathrm{C} ;{ }^{1} \mathrm{H}$ NMR $\left(400 \mathrm{MHz}, \mathrm{CDCl}_{3}\right) \delta: 9.79(\mathrm{~s}, 1 \mathrm{H}), 9.63(\mathrm{~s}, 1 \mathrm{H}), 8.31$ (d, $J=2 \mathrm{~Hz}, 1 \mathrm{H}), 8.24(\mathrm{~s}, 1 \mathrm{H}), 6.87(\mathrm{~d}, J=4 \mathrm{~Hz}, 1 \mathrm{H}), 6.49$ (s, $1 \mathrm{H}), 5.16(\mathrm{~s}, 2 \mathrm{H}), 4.01(\mathrm{~d}, J=2 \mathrm{~Hz}, 2 \mathrm{H}), 3.93(\mathrm{~d}, J=4 \mathrm{~Hz}$, 2H), $3.83(\mathrm{~d}, J=2 \mathrm{~Hz}, 2 \mathrm{H}), 2.14 \sim 2.29(\mathrm{~m}, 3 \mathrm{H}), 2.11$ (s, $3 \mathrm{H}), 1.04 \sim 1.09(\mathrm{~m}, 18 \mathrm{H}) ;{ }^{13} \mathrm{C} \mathrm{NMR}\left(100 \mathrm{MHz}, \mathrm{CDCl}_{3}\right) \delta$ : $170.9,163.2,161.1,158.6,154.3,145.8,143.3,134.2$, $125.5,117.8,114.1,106.6,96.8,76.5,75.0,74.8,61.3$,
28.3, 28.1, 27.9, 21.0, 19.3, 19.2, 19.1. HRMS (ESI) calcd for $\mathrm{C}_{27} \mathrm{H}_{39} \mathrm{~N}_{2} \mathrm{O}_{6}[\mathrm{M}+\mathrm{H}]^{+}:$487.2813, found 487.2808.

\subsection{Synthesis of compound 20}

To a solution of compound $19(0.15 \mathrm{~g}, 0.30 \mathrm{mmol})$ in THF $(10 \mathrm{~mL})$ and $\mathrm{H}_{2} \mathrm{O}(1 \mathrm{~mL})$ was added $\mathrm{LiOH} \cdot \mathrm{H}_{2} \mathrm{O}(25$ $\mathrm{mg}, 0.60 \mathrm{mmol})$. The mixture was stirred under reflux for 12 $\mathrm{h}$ and then concentrated with a rotavapor. The resulting residue was triturated in dichloromethane $(30 \mathrm{~mL})$. The organic solution was washed by water $(10 \mathrm{~mL} \times 3)$ and brine $(10 \mathrm{~mL})$ and dried over sodium sulfate. After removal of the solvent and dryness in vacuo, 5-(hydroxymethyl)-2,4diisobutoxy- $N$-(4-isobutoxypyridin-3-yl)benzamide (20) was obtained as a white solid $(0.12 \mathrm{~g}, 91 \%)$. m.p. $131.8 \sim$ $132.1{ }^{\circ} \mathrm{C} ;{ }^{1} \mathrm{H}$ NMR $\left(400 \mathrm{MHz}, \mathrm{CDCl}_{3}\right) \delta: 9.81(\mathrm{~s}, 1 \mathrm{H}), 9.63$ $(\mathrm{s}, 1 \mathrm{H}), 8.30(\mathrm{~d}, J=4 \mathrm{~Hz}, 1 \mathrm{H}), 8.20(\mathrm{~s}, 1 \mathrm{H}), 6.87(\mathrm{~d}, J=2$ $\mathrm{Hz}, 1 \mathrm{H}), 6.51(\mathrm{~s}, 1 \mathrm{H}), 4.72(\mathrm{~s}, 2 \mathrm{H}), 4.01(\mathrm{~d}, J=2 \mathrm{~Hz}, 2 \mathrm{H})$, $3.93(\mathrm{~d}, J=4 \mathrm{~Hz}, 2 \mathrm{H}), 3.86(\mathrm{~d}, J=4 \mathrm{~Hz}, 2 \mathrm{H}), 2.01 \sim 2.29$ $(\mathrm{m}, 3 \mathrm{H}), 1.04 \sim 1.12(\mathrm{~m}, 18 \mathrm{H}) ;{ }^{13} \mathrm{C} \mathrm{NMR}(100 \mathrm{MHz}$, $\left.\mathrm{CDCl}_{3}\right) \delta: 163.3,161.0,158.2,154.4,145.6,143.1,133.1$, 125.6, 122.9, 114.2, 106.6, 96.9, 76.6, 75.0, 74.8, 61.3, 28.3, 28.1, 27.9, 21.0, 19.3, 19.1. HRMS (ESI) calcd for $\mathrm{C}_{25} \mathrm{H}_{37} \mathrm{~N}_{2} \mathrm{O}_{5}[\mathrm{M}+\mathrm{H}]^{+}:$445.2702, found 445.2699.

\subsection{Synthesis of compound 21}

To a solution of compound $20(0.10 \mathrm{~g}, 0.23 \mathrm{mmol})$ in dichloromethane $(10 \mathrm{~mL})$ was added $\mathrm{MnO}_{2}(0.40 \mathrm{~g}, 4.5$ mmol). The mixture was stirred under reflux for $12 \mathrm{~h}$. The solid was filtered and the solvent was removed with a rotavapor. The resulting residue was subjected to flash column chromatography (dichloromethane) to afford 5formyl-2,4-diisobutoxy- $N$-(4-isobutoxypyridin-3-yl)benzamide (21) as a white solid (90 mg, 90\%). m.p. 153.3 $153.5{ }^{\circ} \mathrm{C} ;{ }^{1} \mathrm{H}$ NMR $\left(400 \mathrm{MHz}, \mathrm{CDCl}_{3}\right) \delta: 10.4(\mathrm{~s}, 1 \mathrm{H}), 9.63$ $(\mathrm{s}, 1 \mathrm{H}), 9.53(\mathrm{~s}, 1 \mathrm{H}), 8.73(\mathrm{~s}, 1 \mathrm{H}), 8.32(\mathrm{~s}, 1 \mathrm{H}), 6.91(\mathrm{~s}, 1 \mathrm{H})$, 6.49 (s, 1H), 4.06 (d, $J=4 \mathrm{~Hz}, 2 \mathrm{H}), 3.95$ (d, $J=4 \mathrm{~Hz}, 2 \mathrm{H})$, $3.91(\mathrm{~d}, J=4 \mathrm{~Hz}, 2 \mathrm{H}), 2.13 \sim 2.30(\mathrm{~m}, 3 \mathrm{H}), 1.04 \sim 1.12(\mathrm{~m}$, $18 \mathrm{H}) ;{ }^{13} \mathrm{C}$ NMR $\left(100 \mathrm{MHz}, \mathrm{CDCl}_{3}\right) \delta: 187.4,165.0,162.5$, $162.4,154.4,145.7,142.9,134.9,125.3,119.3,115.3$, 106.7, 96.4, 76.4, 75.2, 75.0, 28.3, 28.1, 27.8, 19.3, 19.2, 19.1. HRMS (ESI) calcd for $\mathrm{C}_{25} \mathrm{H}_{35} \mathrm{~N}_{2} \mathrm{O}_{5}[\mathrm{M}+\mathrm{H}]^{+}$: 443.2546, found 445.2557.

\subsection{Synthesis of compound 3}

To a solution of 21 (50 mg, $0.11 \mathrm{mmol})$ in $\mathrm{MeOH}(5 \mathrm{~mL})$ and triethylamine $(0.2 \mathrm{~mL})$ was added compound 10 (40 $\mathrm{mg}, 0.11 \mathrm{mmol}$ ). The mixture was stirred under reflux for 12 h. Upon cooling to room temperature, the precipitate formed was filtered and washed with cooled methanol and then dried in vacuo to afford (E)-2,4-diisobutoxy- $N$ - (4isobutoxypyridin-3-yl)-5-((2-(2,3,4-trifluoro-5-iodobenzoyl)hydrazono)methyl)benzamide (3) as a white solid (45 $\mathrm{mg}, 54 \%$ ). ${ }^{1} \mathrm{H}$ NMR indicated that this compound existed as two configurational isomers in a $1: 0.29$ ratio. m.p. 231.2 231.5 ${ }^{\circ} \mathrm{C} ;{ }^{1} \mathrm{H}$ NMR (400 MHz, DMSO- $d_{6}$, major) $\delta$ : $12.01(\mathrm{~s}, 1 \mathrm{H}), 9.80(\mathrm{~s}, 1 \mathrm{H}), 9.29(\mathrm{~s}, 1 \mathrm{H}), 8.60(\mathrm{~s}, 2 \mathrm{H}), 8.22 \sim$ $8.23(\mathrm{~m}, 1 \mathrm{H}), 7.97 \sim 8.01(\mathrm{~m}, 1 \mathrm{H}), 7.17 \sim 7.19(\mathrm{~m}, 1 \mathrm{H}), 6.85$ (s, 1H), 4.16 (d, $J=4 \mathrm{~Hz}, 2 \mathrm{H}), 3.98$ (d, $J=2 \mathrm{~Hz}, 4 \mathrm{H})$, 
$2.01 \sim 2.21(\mathrm{~m}, 3 \mathrm{H}), 0.92 \sim 1.05(\mathrm{~m}, 18 \mathrm{H}) ;{ }^{19} \mathrm{~F}$ NMR $(300$ MHz, DMSO- $d_{6}$, major) $\delta:-110.58 \sim-110.67(\mathrm{~m}, 1 \mathrm{~F})$, $-134.76 \sim-134.86(\mathrm{~m}, 1 \mathrm{~F}),-156.07 \sim-156.20(\mathrm{~m}$, $1 \mathrm{~F}) ;{ }^{1} \mathrm{H}$ NMR (400 MHz, DMSO- $d_{6}$, minor) $\delta: 12.16(\mathrm{~s}$, $1 \mathrm{H}), 9.70(\mathrm{~s}, 1 \mathrm{H}), 9.16(\mathrm{~s}, 1 \mathrm{H}), 8.42(\mathrm{~s}, 1 \mathrm{H}), 8.22 \sim 8.23(\mathrm{~m}$, $1 \mathrm{H}), 8.10(\mathrm{~s}, 1 \mathrm{H}), 7.82 \sim 7.85(\mathrm{~m}, 1 \mathrm{H}), 7.15 \sim 7.16(\mathrm{~m}, 1 \mathrm{H})$, $6.81(\mathrm{~s} 1 \mathrm{H}), 4.11(\mathrm{~d}, J=2 \mathrm{~Hz}, 2 \mathrm{H}), 3.95(\mathrm{~d}, J=4 \mathrm{~Hz}, 4 \mathrm{H})$, $1.94 \sim 2.00(\mathrm{~m}, 3 \mathrm{H}), 0.92 \sim 1.05(\mathrm{~m}, 18 \mathrm{H}) ;{ }^{19} \mathrm{~F}$ NMR $(300$ MHz, DMSO- $d_{6}$, minor) $\delta:-111.89 \sim-112.00(\mathrm{~m}, 1 \mathrm{~F})$, $-132.12 \sim-132.22(\mathrm{~m}, 1 \mathrm{~F}),-157.27 \sim-157.39(\mathrm{~m}$, $1 \mathrm{~F}) ;{ }^{13} \mathrm{C}$ NMR (100 MHz, DMSO- $\left.d_{6}\right) \delta$ : 164.0, 162.8, $162.7,161.8,161.6,160.2,160.0,157.8,154.9,154.7$, $150.9,146.9,146.8,143.7,143.3,143.1,140.9,138.0$, $132.8,132.5,130.1,129.5$. 125.1, 125.0, 123.2, 123.0, 115.8, 115.7, 114.7, 108.2, 98.6, 78.7, 78.6, 78.4, 76.4, 76.3, 75.2, 74.9, 28.3, 28.0, 27.8, 19.6, 19.5, 19.4, 19.2, 19.1. HRMS (ESI) calcd for $\mathrm{C}_{32} \mathrm{H}_{37} \mathrm{~N}_{4} \mathrm{O}_{5} \mathrm{~F}_{3} \mathrm{I} \quad[\mathrm{M}+\mathrm{H}]^{+}$: 741.1761 , found 741.1757 .

\subsection{Synthesis of compound 23}

To a solution of compound $22(0.10 \mathrm{~g}, 0.32 \mathrm{mmol})$ in dichloromethane $(5 \mathrm{~mL})$ were added tert-butyl carbazate (64 mg, $0.48 \mathrm{mmol}$ ), HOBT (86 mg, $0.64 \mathrm{mmol}$ ) and EDCI $(0.12 \mathrm{~g}, 0.64 \mathrm{mmol})$. After stirring at room temperature for $12 \mathrm{~h}$, the solution was washed with water $(2 \mathrm{~mL} \times 3)$ and brine $(2 \mathrm{~mL})$ and dried over sodium sulfate. The solvent was then removed with a rotavapor to afford tert-butyl 2-(2,4diisobutoxy-5-nitrobenzoyl)hydrazine-1-carboxylate (23), after dried in vacuo, as a white solid (0.11 g, 82\%). m.p. 159.2 $160.0{ }^{\circ} \mathrm{C} ;{ }^{1} \mathrm{H}$ NMR $\left(400 \mathrm{MHz}, \mathrm{CDCl}_{3}\right) \delta: 9.32(\mathrm{~s}$, $1 \mathrm{H}), 8.84$ (s, 1H), 6.90 (s, 1H), $6.48(\mathrm{~s}, 1 \mathrm{H}), 3.98$ (d, $J=2$ $\mathrm{Hz}, 2 \mathrm{H}), 3.89$ (d, J=2 Hz, 2H), 2.19 $2.34(\mathrm{~m}, 2 \mathrm{H}), 1.50$ $(\mathrm{s}, 9 \mathrm{H}), 1.09 \sim 1.14(\mathrm{~m}, 12 \mathrm{H}) ;{ }^{13} \mathrm{C} \mathrm{NMR}\left(100 \mathrm{MHz}, \mathrm{CDCl}_{3}\right)$ $\delta: 161.2,157.1,133.3,131.3,123.1,123.0,111.6,97.4$, 81.8, 77.2, 76.1, 28.2, 28.1, 19.3, 19.0. HRMS (ESI) calcd for $\mathrm{C}_{20} \mathrm{H}_{32} \mathrm{~N}_{3} \mathrm{O}_{7}[\mathrm{M}+\mathrm{H}]^{+}:$426.2240, found 426.2242.

\subsection{Synthesis of compound 24}

To a solution of compound $23(0.11 \mathrm{~g}, 0.27 \mathrm{mmol})$ in $\mathrm{MeOH}(5 \mathrm{~mL})$ was added $10 \% \mathrm{Pd} / \mathrm{C}(11 \mathrm{mg})$. The mixture was stirred at room temperature under $\mathrm{H}_{2}$ atmosphere through a balloon for $12 \mathrm{~h}$. The solid was filtered and the solvent was removed with a rotavapor. The resulting residue was subjected to column chromatography (dichloromethane) to afford tert-butyl 2-(5-amino-2,4-diisobutoxybenzoyl)hydrazine-1-carboxylate (24) as a pale yellow solid (0.10 g, 82\%). m.p. 183.6 183.9 ${ }^{\circ} \mathrm{C} ;{ }^{1} \mathrm{H}$ NMR (400 MHz, $\left.\mathrm{CDCl}_{3}\right) \delta: 9.57(\mathrm{~s}, 1 \mathrm{H}), 7.51(\mathrm{~s}, 1 \mathrm{H}), 7.01(\mathrm{~s}, 1 \mathrm{H}), 6.37(\mathrm{~s}$, $1 \mathrm{H}), 3.81(\mathrm{~d}, J=2 \mathrm{~Hz}, 2 \mathrm{H}), 3.76(\mathrm{~d}, J=4 \mathrm{~Hz}, 2 \mathrm{H}), 3.64$ (s, $2 \mathrm{H}), 2.10 \sim 2.21(\mathrm{~m}, 2 \mathrm{H}), 1.46(\mathrm{~s}, 9 \mathrm{H}), 1.03 \sim 1.07(\mathrm{~m}$, $12 \mathrm{H}) ;{ }^{13} \mathrm{C}$ NMR $\left(100 \mathrm{MHz}, \mathrm{CDCl}_{3}\right) \delta: 164.8,155.3,151.2$, 150.7, 130.3, 117.3, 111.4, 81.1, 76.5, 74.7, 28.4, 28.3, 28.1, 19.4, 19.3. HRMS (ESI) calcd for $\mathrm{C}_{20} \mathrm{H}_{34} \mathrm{~N}_{3} \mathrm{O}_{5}[\mathrm{M}+\mathrm{H}]^{+}$: 396.2498, found 396.2493.

\subsection{Synthesis of compound 25}

To a solution of compound $24(61 \mathrm{mg}, 0.15 \mathrm{mmol})$ in dichloromethane $(5 \mathrm{~mL})$ and $\mathrm{DMF}(5 \mathrm{~mL})$ were added compounds 8 (56 mg, $0.19 \mathrm{mmol})$, HATU (90 mg, 0.23 mmol) and DIPEA (99 mg, $0.77 \mathrm{mmol})$. The mixture was stirred at room temperature for $12 \mathrm{~h}$ and then concentrated with a rotavapor. The resulting residue was triturated with dichloromethane $(10 \mathrm{~mL})$. The solution was washed with water $(5 \mathrm{~mL} \times 3)$ and brine $(5 \mathrm{~mL})$ and dried over sodium sulfate. The solvent was removed with a rotavapor and the resulting residue subjected to column chromatography (dichloromethane/methanol, $V: V=30: 1$ ) to afford tert-butyl 2-(2,4-diisobutoxy-5-(2,3,4-trifluoro-5-iodobenzamido)benzoyl)hydrazine-1-carboxylate (25) as a white solid (53 mg, 51\%). m.p. 161.2 162.0 ${ }^{\circ} \mathrm{C} ;{ }^{1} \mathrm{H}$ NMR (400 $\left.\mathrm{MHz}, \mathrm{CDCl}_{3}\right) \delta: 9.50(\mathrm{~s}, 1 \mathrm{H}), 9.17(\mathrm{~s}, 1 \mathrm{H}), 8.77(\mathrm{~d}, J=6 \mathrm{~Hz}$, $1 \mathrm{H}), 8.44 \sim 8.47(\mathrm{~m}, 1 \mathrm{H}), 6.95(\mathrm{~s}, 1 \mathrm{H}), 6.50(\mathrm{~s}, 1 \mathrm{H}), 3.93(\mathrm{~d}$, $J=2 \mathrm{~Hz}, 2 \mathrm{H}), 3.89$ (d, $J=4 \mathrm{~Hz}, 2 \mathrm{H}), 3.64$ (s, 2H), 2.18 $2.32(\mathrm{~m}, 2 \mathrm{H}), 1.52(\mathrm{~s}, 9 \mathrm{H}), 1.12 \sim 1.15(\mathrm{~m}, 12 \mathrm{H}) ;{ }^{13} \mathrm{C} \mathrm{NMR}$ $\left(100 \mathrm{MHz}, \mathrm{CDCl}_{3}\right) \delta: 163.7,157.3,155.2,155.1,154.3$, $154.2,151.9,151.8,151.7,151.0,150.9,148.5,148.4$, $140.6,140.4,140.3,138.1,137.9,137.7,134.9,124.5$, $120.8,120.1,111.7,96.3,81.4,76.2,75.4,28.4,28.4,28.3$, $19.4,19.1 ;{ }^{19} \mathrm{~F}$ NMR $\left(300 \mathrm{MHz}, \mathrm{CDCl}_{3}\right) \delta:-105.96 \sim-$ $106.06(\mathrm{~m}, 1 \mathrm{~F}),-134.84 \sim-134.99(\mathrm{~m}, 1 \mathrm{~F}),-154.80 \sim$ $-154.92(\mathrm{~m}, 1 \mathrm{~F})$. HRMS (ESI) calcd for $\mathrm{C}_{27} \mathrm{H}_{34} \mathrm{~F}_{3} \mathrm{IN}_{3} \mathrm{O}_{6}$ $[\mathrm{M}+\mathrm{H}]^{+}: 680.1444$, found 680.1446 .

\subsection{Synthesis of compound 26}

To a round-bottom flask was added compound $25(0.10 \mathrm{~g}$, $0.15 \mathrm{mmol}$ ) and a solution of hydrochloric in ethyl acetate $\left(2 \mathrm{~mol} \cdot \mathrm{L}^{-1}, 2 \mathrm{~mL}\right)$. The mixture was stirred at room temperature for $2 \mathrm{~h}$. The solid formed was filtered and washed with cold ethyl acetate and then dried in vacuo to afford 2,3,4-trifluoro- $N$-(5-(hydrazinecarbonyl)-2,4-diisobutoxyphenyl)-5-iodobenzamide (26) as a white solid (90 mg, 90\%). m.p. 233.9 234.8 ${ }^{\circ} \mathrm{C}$; ${ }^{1} \mathrm{H}$ NMR $(400 \mathrm{MHz}$, DMSO- $\left.d_{6}\right) \delta: 9.91 \sim 10.01(\mathrm{~m}, 1 \mathrm{H}), 9.66(\mathrm{~s}, 1 \mathrm{H}), 8.22(\mathrm{~s}$, $1 \mathrm{H}), 8.01 \sim 8.05(\mathrm{~m}, 1 \mathrm{H}), 6.84(\mathrm{~s}, 1 \mathrm{H}), 4.00(\mathrm{~d}, J=2 \mathrm{~Hz}$, $2 \mathrm{H}), 3.95(\mathrm{~d}, J=4 \mathrm{~Hz}, 2 \mathrm{H}), 3.64(\mathrm{~s}, 2 \mathrm{H}), 2.16 \sim 2.22(\mathrm{~m}$, $1 \mathrm{H}), 2.05 \sim 2.15(\mathrm{~m}, 1 \mathrm{H}), 1.02 \sim 1.03(\mathrm{~m}, 12 \mathrm{H}) ;{ }^{13} \mathrm{C} \mathrm{NMR}$ $\left(100 \mathrm{MHz}, \mathrm{DMSO}-d_{6}\right) \delta: 164.5,159.9,156.7,156.0,153.4$, $153.3,151.0,150.9,150.3,150.2,147.8,147.7,147.6$, $140.6,140.4,140.3,138.1,137.9,137.7,133.1,126.9$, $123.4,119.6,110.8,98.5,76.0,75.3,28.3,27.9,19.7,19.4$. ${ }^{19} \mathrm{~F}$ NMR $\left(300 \mathrm{MHz}, \mathrm{DMSO}-d_{6}\right) \delta:-110.56 \sim-110.64$ $(\mathrm{m}, 1 \mathrm{~F}),-134.64 \sim-134.74(\mathrm{~m}, 1 \mathrm{~F}),-156.15 \sim-$ $156.26(\mathrm{~m}, 1 \mathrm{~F})$. HRMS (ESI) calcd for $\mathrm{C}_{22} \mathrm{H}_{26} \mathrm{~F}_{3} \mathrm{IN}_{3} \mathrm{O}_{4}[\mathrm{M}$ $+\mathrm{H}]^{+}: 580.0920$, found 580.0923 .

\subsection{Synthesis of compound 4}

To a solution of compound 26 (42 $\mathrm{mg}, 0.068 \mathrm{mmol})$ in $\mathrm{MeOH}(5 \mathrm{~mL})$ and triethylamine $(0.2 \mathrm{~mL})$ was added compound 21 (30 mg, $0.068 \mathrm{mmol}$ ). The mixture was stirred under reflux for $12 \mathrm{~h}$ and then cooled to room temperature. The solid formed was filtered and washed with cold methanol and then dried in vacuo to afford $(E)-N-(5-$ (2-(2,4-diisobutoxy-5-((4-isobutoxypyridin-3-yl)carbamoyl)benzylidene)hydrazine-1-carbonyl)-2,4-diisobutoxyphenyl)-2,3,4-trifluoro-5-iodobenzamide (4) as a white solid (60 mg, 90\%). m.p. 236.1 236.6 ${ }^{\circ} \mathrm{C} ;{ }^{1} \mathrm{H}$ NMR indicated 
that the compound existed as two configurational isomers in a $1: 0.07$ ratio. ${ }^{1} \mathrm{H}$ NMR $\left(400 \mathrm{MHz}, \mathrm{DMSO}-d_{6}\right.$, major) $\delta$ : $11.33(\mathrm{~s}, 1 \mathrm{H}), 10.11(\mathrm{~s}, 1 \mathrm{H}), 9.6(\mathrm{~s}, 1 \mathrm{H}), 9.55(\mathrm{~s}, 1 \mathrm{H}), 8.60$ $(\mathrm{s}, 1 \mathrm{H}), 8.56(\mathrm{~d}, J=4 \mathrm{~Hz}, 1 \mathrm{H}), 8.50(\mathrm{~s}, 1 \mathrm{H}), 8.11(\mathrm{~s}, 1 \mathrm{H})$, $8.02 \sim 8.06(\mathrm{~m} 1 \mathrm{H}), 7.67(\mathrm{~d}, J=4 \mathrm{~Hz}, 1 \mathrm{H}), 6.88(\mathrm{~s}, 1 \mathrm{H})$, $6.82(\mathrm{~s}, 1 \mathrm{H}), 4.19 \sim 4.25(\mathrm{~m}, 4 \mathrm{H}), 3.92 \sim 4.01(\mathrm{~m}, 6 \mathrm{H})$, $2.04 \sim 2.22(\mathrm{~m}, 5 \mathrm{H}), 0.98 \sim 1.06(\mathrm{~m}, 30 \mathrm{H}) ;{ }^{1} \mathrm{H}$ NMR $(400$ MHz, DMSO-d $) \delta: 11.59(\mathrm{~s}, 1 \mathrm{H}), 9.97(\mathrm{~s}, 1 \mathrm{H}), 9.50(\mathrm{~s}, 1 \mathrm{H})$, $9.40(\mathrm{~s}, 1 \mathrm{H}), 8.60(\mathrm{~s}, 1 \mathrm{H}), 8.50(\mathrm{~s}, 1 \mathrm{H}), 8.33(\mathrm{~s}, 1 \mathrm{H}), 8.14(\mathrm{~s}$, $1 \mathrm{H}), 7.77(\mathrm{~s} 1 \mathrm{H}), 7.56 \sim 7.57(\mathrm{~s}, 1 \mathrm{H}), 6.88(\mathrm{~s}, 1 \mathrm{H}), 6.77(\mathrm{~s}$, $1 \mathrm{H}), 4.19 \sim 4.25(\mathrm{~m}, 4 \mathrm{H}), 3.92 \sim 4.01(\mathrm{~m}, 6 \mathrm{H}), 2.04 \sim 2.22$ $(\mathrm{m}, 5 \mathrm{H}), 0.98 \sim 1.06(\mathrm{~m}, 30 \mathrm{H}) ;{ }^{19} \mathrm{~F}$ NMR $(300 \mathrm{MHz}$, DMSO- $d_{6}$, minor) $\delta:-110.65 \sim-110.76(\mathrm{~m}, 1 \mathrm{~F}),-$ $134.62 \sim-134.72(\mathrm{~m}, 1 \mathrm{~F}),-156.21 \sim-156.33(\mathrm{~m}, 1 \mathrm{~F})$; ${ }^{13} \mathrm{C}$ NMR (100 MHz, DMSO-d $) \delta: 163.5,162.0,161.7$, $160.0,159.8,158.8,157.4,156.0,155.1,153.4,148.1$, $147.9,147.8,141.4,141.3,141.1,138.0,135.5,135.4$, $135.3,133.2,130.0,127.0,126.9,123.4,119.6,116.6$, $114.5,113.9,109.8,109.5,98.7,98.6,78.6,78.4,76.7,76.5$, 75.7, 75.3, 75.2, 28.4, 28.3, 28.0, 19.6, 19.5, 19.4, 19.1 . HRMS (ESI) calcd for $\mathrm{C}_{47} \mathrm{H}_{58} \mathrm{~F}_{3} \mathrm{IN}_{5} \mathrm{O}_{8}[\mathrm{M}+\mathrm{H}]{ }^{+}$: 1004.3282, found 1004.3281 .

\subsection{Synthesis of compound 27}

To a solution of compound $22(0.15 \mathrm{~g}, 0.48 \mathrm{mmol})$ in dry dichloromethane $(5 \mathrm{~mL})$ and DMF $(0.05 \mathrm{~mL})$ was added $(\mathrm{COCl})_{2}(0.2 \mathrm{~mL}, 4.8 \mathrm{mmol})$. The mixture was stirred at room temperature for $4 \mathrm{~h}$ and then concentrated under reduced pressure. The resulting acyl chloride was dissolved again in dichloromethane $(5 \mathrm{~mL})$ and to the the solution were added compound 18 (79 $\mathrm{mg}, 0.48 \mathrm{mmol})$ and triethylamine ( $63 \mathrm{mg}, 0.68 \mathrm{mmol})$. Stirring was continued for $2 \mathrm{~h}$ and the solution washed with water $(2 \mathrm{~mL} \times 3)$ and brine $(2 \mathrm{~mL})$ and dried over sodium sulfate. Upon removal of the solvent with a rotavapor, the resulting reside was subjected to column chromatography (dichloromethane/ methanol, $V: V=30: 1)$ to afford 2,4-diisobutoxy- $N$ (4-isobutoxypyridin-3-yl)-5-nitrobenzamide (27) as a white solid (60 mg, 26\%). m.p. 106.3 106.7 ${ }^{\circ} \mathrm{C} ;{ }^{1} \mathrm{H}$ NMR (400 $\left.\mathrm{MHz}_{2} \mathrm{CDCl}_{3}\right) \delta: 9.54(\mathrm{~s}, 2 \mathrm{H}), 8.92(\mathrm{~s}, 1 \mathrm{H}), 8.31(\mathrm{~d}, J=2 \mathrm{~Hz}$, $1 \mathrm{H}), 6.86(\mathrm{~d}, J=4 \mathrm{~Hz}, 1 \mathrm{H}), 6.57(\mathrm{~s}, 1 \mathrm{H}), 4.07(\mathrm{~d}, J=4 \mathrm{~Hz}$, $2 \mathrm{H}), 3.94 \sim 3.90(\mathrm{~m}, 4 \mathrm{H}), 2.11 \sim 2.32(\mathrm{~m}, 3 \mathrm{H}), 1.04 \sim 1.13$ $(\mathrm{m}, 18 \mathrm{H}) ;{ }^{13} \mathrm{C}$ NMR $\left(100 \mathrm{MHz}, \mathrm{CDCl}_{3}\right) \delta: 161.2,160.8$, $156.9,154.3,146.3,146.2,143.3,143.2,133.4,131.4$, $124.9,114.3,106.7,98.0,76.8,76.1,75.0,28.3,28.0,27.8$, 19.2, 19.1, 19.0. HRMS (ESI) calcd for $\mathrm{C}_{24} \mathrm{H}_{34} \mathrm{~N}_{3} \mathrm{O}_{6}[\mathrm{M}+$ $\mathrm{H}]^{+}:$460.2448, found 450.2459 .

\subsection{Synthesis of compound 28}

To a solution of compound $27(0.20 \mathrm{~g}, 0.46 \mathrm{mmol})$ in EtOH $(10 \mathrm{~mL})$ and $\mathrm{H}_{2} \mathrm{O}(1 \mathrm{~mL})$ was added $\mathrm{NH}_{4} \mathrm{Cl}(0.40 \mathrm{~g}$, $7.4 \mathrm{mmol})$ and iron powder $(0.26 \mathrm{~g}, 4.6 \mathrm{mmol})$. The mixture was heated to $80{ }^{\circ} \mathrm{C}$ for $12 \mathrm{~h}$ and then the solid was filtrated off. To the solution was added dilute sodium bicarbonate solution $\left(2 \mathrm{~mol} \cdot \mathrm{L}^{-1}, 5 \mathrm{~mL}\right)$ and the mixture was stirred for 20 minutes and then concentrated under reduced pressure. The resulting residue was triturated in ethyl acetate $(30 \mathrm{~mL})$ and the solution washed by water $(10 \mathrm{~mL} \times 3)$, brine $(10$
$\mathrm{mL}$ ) and dried over sodium sulfate. Upon removal of the solvent with a rotavapor, the resulting residue was subjected to column chromatography (dichloromethane/methanol, $V: V=25: 1)$ to afford 5-amino-2,4-diisobutoxy- $N$-(4isobutoxypyridin-3-yl)benzamide (28) as a pale yellow solid (0.15 g, 80\%). m.p. $119.8 \sim 120.0{ }^{\circ} \mathrm{C} ;{ }^{1} \mathrm{H}$ NMR (400 $\left.\mathrm{MHz}, \mathrm{CDCl}_{3}\right) \delta: 10.0(\mathrm{~s}, 1 \mathrm{H}), 9.64(\mathrm{~s}, 1 \mathrm{H}), 8.29(\mathrm{~d}, \quad J=2$ $\mathrm{Hz}, 1 \mathrm{H}), 7.61(\mathrm{~s}, 1 \mathrm{H}), 6.86(\mathrm{~d}, J=2 \mathrm{~Hz}, 1 \mathrm{H}), 6.48(\mathrm{~s}, 1 \mathrm{H})$, $3.91 \sim 3.92(\mathrm{~m}, 4 \mathrm{H}), 3.83(\mathrm{~d}, J=4 \mathrm{~Hz}, 2 \mathrm{H}), 3.69(\mathrm{~s}, 1 \mathrm{H})$, $2.14 \sim 2.23(\mathrm{~m}, 3 \mathrm{H}), 1.01 \sim 1.11(\mathrm{~m}, 18 \mathrm{H}) ;{ }^{13} \mathrm{C}$ NMR $(100$ $\left.\mathrm{MHz}, \mathrm{CDCl}_{3}\right) \delta: 163.7,154.2,150.8,145.5,143.0,130.7$, $125.7,117.3,114.6,106.5,98.7,77.7,74.9,74.8,28.3,28.2$, $27.9,19.3,19.1$. HRMS (ESI) calcd for $\mathrm{C}_{24} \mathrm{H}_{36} \mathrm{~N}_{3} \mathrm{O}_{4}[\mathrm{M}+$ $\mathrm{H}]^{+}:$430.2706, found 430.2700.

\subsection{Synthesis of compound 29}

Acyl chloride 17 was first prepared from $16(0.12 \mathrm{~g}, 0.28$ $\mathrm{mmol})$ and then dissolved in dichloromethane $(5 \mathrm{~mL})$. To the solution were added $28(0.11 \mathrm{~g}, 0.34 \mathrm{mmol})$, triethylamine (63 $\mathrm{mg}, 0.68 \mathrm{mmol})$. The solution was stirred at room temperature for $2 \mathrm{~h}$ and then washed with water $(2 \mathrm{~mL} \times 3)$, brine $(2 \mathrm{~mL})$ and dried over sodium sulfate. After removal of the solvent, the resulting residue was subjected to column chromatography (dichloromethane/methanol, $V: V=30: 1$ ) to afford 5-((2,4-diisobutoxy-5-((4-isobutoxypyridin-3-yl)carbamoyl)phenyl)carbamoyl)-2,4-diisobutoxybenzyl acetate (29) as a white solid (144 mg, 69\%). m.p. 115.2 $115.6{ }^{\circ} \mathrm{C} ;{ }^{1} \mathrm{H}$ NMR $\left(400 \mathrm{MHz}, \mathrm{DMSO}-d_{6}\right) \delta: 9.94(\mathrm{~s}, 1 \mathrm{H})$, $9.78(\mathrm{~s}, 1 \mathrm{H}), 9.35(\mathrm{~s}, 1 \mathrm{H}), 8.92(\mathrm{~s}, 1 \mathrm{H}), 8.24(\mathrm{~d}, J=2 \mathrm{~Hz}$, 1H), 7.99 (s, 1H), 7.19 (d, $J=4 \mathrm{~Hz}, 1 \mathrm{H}), 6.95$ (s, 1H), 6.82 $(\mathrm{s}, 1 \mathrm{H}), 5.06(\mathrm{~s}, 2 \mathrm{H}), 4.14(\mathrm{~d}, J=2 \mathrm{~Hz}, 2 \mathrm{H}), 4.00 \sim 4.05(\mathrm{~m}$, $4 \mathrm{H}), 3.94(\mathrm{~d}, J=4 \mathrm{~Hz}, 2 \mathrm{H}), 2.05 \sim 2.20(\mathrm{~m}, 5 \mathrm{H}), 2.03(\mathrm{~s}$, $3 \mathrm{H}), 0.97 \sim 1.03(\mathrm{~m}, 30 \mathrm{H}) ;{ }^{13} \mathrm{C} \mathrm{NMR}\left(100 \mathrm{MHz}, \mathrm{CDCl}_{3}\right) \delta$ : $163.0,161.3,160.9,156.6,155.0,154.1,153.9,145.5$, $142.9,133.4,131.3,127.7,127.6,125.7,121.1,114.9$, $114.8,106.6,98.0,97.9,76.1,75.4,75.0,28.3,28.2,28.1$, 27.9, 19.3, 19.2, 19.1, 19.0. HRMS (ESI) calcd for $\mathrm{C}_{42} \mathrm{H}_{60} \mathrm{~N}_{3} \mathrm{O}_{9}[\mathrm{M}+\mathrm{H}]^{+}: 750.4330$, found 750.4351 .

\subsection{Synthesis of compound $\mathbf{3 0}$}

To a solution of compound $29(0.13 \mathrm{~g}, 0.17 \mathrm{mmol})$ in THF $(10 \mathrm{~mL})$ and $\mathrm{H}_{2} \mathrm{O}(1 \mathrm{~mL})$ was added $\mathrm{LiOH} \cdot \mathrm{H}_{2} \mathrm{O}(15$ $\mathrm{mg}, 37 \mathrm{mmol})$. The mixture was stirred under reflux for $12 \mathrm{~h}$ and then concentrated under reduced pressure. The resulting residue was triturated in dichloromethane $(30 \mathrm{~mL})$. The organic layer was washed with water $(10 \mathrm{~mL} \times 3)$, brine $(10$ $\mathrm{mL})$ and dried over sodium sulfate. The solvent was then removed and the resulting residue was subjected column chromatography (dichloromethane/methanol, $V: V=15$ : 1) to afford $N$-(2,4-diisobutoxy-5-((4-isobutoxypyridin-3yl)carbamoyl)phenyl)-5-(hydroxymethyl)-2,4-diisobutoxybenzamide (30) as a white solid $(0.10 \mathrm{~g}, 81 \%)$. m.p. $112.8 \sim$ $113.4{ }^{\circ} \mathrm{C} ;{ }^{1} \mathrm{H}$ NMR $\left(400 \mathrm{MHz}, \mathrm{CDCl}_{3}\right) \delta: 9.74(\mathrm{~s}, 1 \mathrm{H}), 9.70$ $(\mathrm{s}, 1 \mathrm{H}), 9.54(\mathrm{~s}, 1 \mathrm{H}), 8.89(\mathrm{~s}, 1 \mathrm{H}), 8.30(\mathrm{~d}, J=4 \mathrm{~Hz}, 1 \mathrm{H})$, $8.20(\mathrm{~s}, 1 \mathrm{H}), 6.90(\mathrm{~d}, J=4 \mathrm{~Hz}, 1 \mathrm{H}), 6.56(\mathrm{~s}, 1 \mathrm{H}), 6.50(\mathrm{~s}$, $1 \mathrm{H}), 4.71(\mathrm{~s}, 2 \mathrm{H}), 3.94 \sim 3.99(\mathrm{~m}, 6 \mathrm{H}), 3.85 \sim 3.88(\mathrm{~m}, 4 \mathrm{H})$, $2.11 \sim 2.26(\mathrm{~m}, 5 \mathrm{H}), 1.04 \sim 1.12(\mathrm{~m}, 30 \mathrm{H}) ;{ }^{13} \mathrm{C} \mathrm{NMR}(100$ $\left.\mathrm{MHz}, \mathrm{CDCl}_{3}\right) \delta: 163.3,163.2,160.7,158.2,154.6,154.0$, 
$153.9,145.6,143.1,133.1,127.4,125.7,122.6,121.9$, 115.0, 114.5, 106.5, 98.0, 96.9, 76.9, 76.5, 75.4, 74.9, 74.7, $61.4,28.4,28.2,28.1,27.9,19.4,19.3,19.2,19.1$. HRMS (ESI) calcd for $\mathrm{C}_{40} \mathrm{H}_{58} \mathrm{~N}_{3} \mathrm{O}_{8}[\mathrm{M}+\mathrm{H}]^{+}:$708.4224, found 708.4240 .

\subsection{Synthesis of compound $\mathbf{3 1}$}

To a solution of compound $\mathbf{3 0}(90 \mathrm{mg}, 0.13 \mathrm{mmol})$ in dichloromethane $(10 \mathrm{~mL})$ was added $\mathrm{MnO}_{2}(0.21 \mathrm{~g}, 2.5$ mmol). The mixture was stirred under reflux for $12 \mathrm{~h}$. After workup as described for compound 21, $N$-(2,4-diisobutoxy5-((4-isobutoxypyridin-3-yl)carbamoyl)phenyl)-5-formyl2,4-diisobutoxybenzamide (31) was obtained as a white solid (50 mg, 54\%). m.p. 162.2 163.1 ${ }^{\circ} \mathrm{C} ;{ }^{1} \mathrm{H}$ NMR (400 $\left.\mathrm{MHz}, \mathrm{CDCl}_{3}\right) \delta: 10.37(\mathrm{~s}, 1 \mathrm{H}), 9.79(\mathrm{~s}, 1 \mathrm{H}), 9.72(\mathrm{~s}, 1 \mathrm{H})$, $9.21(\mathrm{~s}, 1 \mathrm{H}), 8.78(\mathrm{~s}, 1 \mathrm{H}), 8.73(\mathrm{~s}, 1 \mathrm{H}), 8.25(\mathrm{~d}, J=2 \mathrm{~Hz}$, $1 \mathrm{H}), 6.98(\mathrm{~d}, J=2 \mathrm{~Hz}, 1 \mathrm{H}), 6.57(\mathrm{~s}, 1 \mathrm{H}), 6.48(\mathrm{~s}, 1 \mathrm{H})$, $4.00 \sim 4.04(\mathrm{~m}, 6 \mathrm{H}), 3.87 \sim 3.91(\mathrm{~m}, 4 \mathrm{H}), 2.11 \sim 2.25(\mathrm{~m}$, $5 \mathrm{H}), 1.03 \sim 1.11(\mathrm{~m}, 30 \mathrm{H}) ;{ }^{13} \mathrm{C} \mathrm{NMR}\left(100 \mathrm{MHz}, \mathrm{CDCl}_{3}\right) \delta$ : $187.5,164.8,163.1,162.7,162.4,154.8,154.0,153.8$, $145.5,142.9,134.6,127.3,125.7,121.5,119.1,115.7$, $114.8,106.5,97.9,96.4,76.3,75.4,75.1,74.9,28.3,28.2$, 28.1, 28.0, 19.3, 19.2, 19.1. HRMS (ESI) calcd for $\mathrm{C}_{40} \mathrm{H}_{56} \mathrm{~N}_{3} \mathrm{O}_{8}[\mathrm{M}+\mathrm{H}]^{+}$: 706.4067, found 706.4082.

\subsection{Synthesis of compound 5}

To a solution of compound $\mathbf{3 1}(18 \mathrm{mg}, 0.028 \mathrm{mmol})$ in $\mathrm{MeOH}(5 \mathrm{~mL})$ and triethylamine $(0.2 \mathrm{~mL})$ was added compound 26 (20 mg, $0.028 \mathrm{mmol})$. The mixture was heated under reflux for $12 \mathrm{~h}$ and cooled to room temperature. The solid formed was filtered and washed with cold methanol and dried in vacuo to afford $(E)-N-(5-(2-(5-$ ((2,4-diisobutoxy-5-((4-isobutoxypyridin-3-yl)carbamoyl)phenyl)carbamoyl)-2,4-diisobutoxybenzylidene)hydrazine1-carbonyl)-2,4-diisobutoxyphenyl)-2,3,4-trifluoro-5-iodobenzamide (5) as a white solid (20 mg, 52\%). ${ }^{1} \mathrm{H}$ NMR indicated that this compound existed as two configurational isomers with a $1: 0.11$ ratio. m.p. $226.8 \sim 227.5{ }^{\circ} \mathrm{C} ;{ }^{1} \mathrm{H}$ NMR (400 MHz, DMSO- $d_{6}$, major) $\delta: 11.30(\mathrm{~s}, 1 \mathrm{H}), 10.14$ $(\mathrm{s}, 1 \mathrm{H}), 9.77(\mathrm{~s}, 1 \mathrm{H}), 9.62 \sim 9.63(\mathrm{~m}, 1 \mathrm{H}), 9.54(\mathrm{~s}, 1 \mathrm{H}), 8.92$ $(\mathrm{s}, 1 \mathrm{H}), 8.59(\mathrm{~s}, 1 \mathrm{H}), 8.53(\mathrm{~s}, 1 \mathrm{H}), 8.44 \sim 8.55(\mathrm{~m} 1 \mathrm{H}), 8.14$ $(\mathrm{s}, 1 \mathrm{H}), 8.04 \sim 8.08(\mathrm{~m}, 1 \mathrm{H}), 7.50 \sim 7.52(\mathrm{~s}, 1 \mathrm{H}), 6.99(\mathrm{~s}$, $1 \mathrm{H}), 6.87(\mathrm{~s}, 1 \mathrm{H}), 6.84(\mathrm{~s}, 1 \mathrm{H}), 3.94 \sim 4.18(\mathrm{~m}, 14 \mathrm{H}), 2.06 \sim$ $2.21(\mathrm{~m}, 7 \mathrm{H}), 0.99 \sim 1.08(\mathrm{~m}, 42 \mathrm{H})$; ${ }^{1} \mathrm{H}$ NMR $(400 \mathrm{MHz}$, DMSO- $\mathrm{d}_{6}$, minor) $\delta: 11.56(\mathrm{~s}, 1 \mathrm{H}), 10.06(\mathrm{~s}, 1 \mathrm{H}), 9.77(\mathrm{~s}$, $1 \mathrm{H}), 9.62 \sim 9.63(\mathrm{~m}, 1 \mathrm{H}), 9.45 \sim 9.48(\mathrm{~m}, 1 \mathrm{H}), 8.78(\mathrm{~s}, 1 \mathrm{H})$, $8.59(\mathrm{~s}, 1 \mathrm{H}), 8.53(\mathrm{~s}, 1 \mathrm{H}), 8.34(\mathrm{~s} 1 \mathrm{H}), 8.16(\mathrm{~s}, 1 \mathrm{H}), 7.85(\mathrm{~s}$, $1 \mathrm{H}), 7.42 \sim 7.44(\mathrm{~m}, 1 \mathrm{H}), 6.94(\mathrm{~s}, 1 \mathrm{H}), 6.80(\mathrm{~s}, 1 \mathrm{H}), 6.76(\mathrm{~s}$, $1 \mathrm{H}), 3.94 \sim 4.18(\mathrm{~m}, 14 \mathrm{H}), 2.06 \sim 2.21(\mathrm{~m}, 7 \mathrm{H}), 0.99 \sim 1.08$ $(\mathrm{m}, 42 \mathrm{H}) ;{ }^{19} \mathrm{~F}$ NMR $\left(300 \mathrm{MHz}, \mathrm{DMSO}-d_{6}\right.$, minor $) \delta:-$ $110.68 \sim-110.80(\mathrm{~m}, 1 \mathrm{~F}),-134.61 \sim-134.70(\mathrm{~m}, 1 \mathrm{~F})$, $-156.24 \sim-156.36(\mathrm{~m}, 1 \mathrm{~F}) ;{ }^{13} \mathrm{C} \mathrm{NMR}(100 \mathrm{MHz}$, DMSO-d $) \delta: 163.3,162.7,161.6,161.3,159.8,159.7$, $156.9,156.8,156.0,155.0,154.8,153.7,150.9,143.3$, $141.3,133.2,130.1,129.7,127.0,126.4,125.0,121.9$, $119.5,116.1,115.1,114.3,112.9,109.0,99.3,98.6,98.4$, $76.5,76.3,76.0,75.6,75.5,75.2,75.0,28.4,28.3,28.1$, 28.0, 27.7, 19.6, 19.5, 19.4, 19.3, 19.1. HRMS (ESI) calcd for $\mathrm{C}_{62} \mathrm{H}_{79} \mathrm{~F}_{3} \mathrm{IN}_{6} \mathrm{O}_{11}[\mathrm{M}+\mathrm{H}]^{+}:$1267.4804, found 1267.4819 .

\subsection{Synthesis of compound 32}

Compound 22 ( $0.14 \mathrm{~g}, 0.32 \mathrm{mmol})$ was first converted to the acyl chloride with $(\mathrm{COCl})_{2}(0.2 \mathrm{~mL}, 4.8 \mathrm{mmol})$ in dry DCM $(5 \mathrm{~mL})$ and DMF $(0.05 \mathrm{~mL})$. After workup, the acyl chloride was dissolved in dichloromethane $(5 \mathrm{~mL})$ and to the solution were added compound $28(0.13 \mathrm{~g}, 0.41 \mathrm{mmol})$ and triethylamine $(63 \mathrm{mg}, 0.68 \mathrm{mmol})$. The mixture was stirred at room temperature for $2 \mathrm{~h}$. After workup, the crude product was subjected to column chromatography (dichloromethane/methanol, $V: V=30: 1)$ to $N$-(2,4-diisobutoxy-5-((4-isobutoxypyridin-3-yl)carbamoyl)phenyl)-2,4diisobutoxy-5-nitrobenzamide (32) an a white solid $(0.13 \mathrm{~g}$, 55\%). m.p. $172.7 \sim 173.0{ }^{\circ} \mathrm{C}$; ${ }^{1} \mathrm{H}$ NMR (400 MHz, $\mathrm{CDCl}_{3}$ ) $\delta$ : $9.71(\mathrm{~s}, 1 \mathrm{H}), 9.66(\mathrm{~s}, 1 \mathrm{H}), 9.29(\mathrm{~s}, 1 \mathrm{H}), 8.89(\mathrm{~s}, 1 \mathrm{H}), 8.83$ (s, 1H), 8.27 (d, $J=2 \mathrm{~Hz}, 1 \mathrm{H}), 6.84$ (d, $J=2 \mathrm{~Hz}, 1 \mathrm{H}), 6.58$ (s, 1H), $4.06(\mathrm{~d}, J=2 \mathrm{~Hz}, 2 \mathrm{H}), 3.98(\mathrm{~d}, J=4 \mathrm{~Hz}, 2 \mathrm{H})$, $3.87 \sim 3.92(\mathrm{~m}, 6 \mathrm{H}), 2.10 \sim 2.31(\mathrm{~m}, 5 \mathrm{H}), 1.03 \sim 1.10(\mathrm{~m}$, $30 \mathrm{H}) ;{ }^{13} \mathrm{C} \mathrm{NMR}\left(100 \mathrm{MHz}, \mathrm{CDCl}_{3}\right) \delta: 163.0,161.3,160.9$, $156.6,155.0,154.1,154.0,145.5,142.9,133.4,131.3$, 127.7, 127.6, 125.7, 121.1, 114.9, 114.8, 106.6, 98.0, 76.1, 75.4, 75.0, 28.3, 28.2, 28.1, 27.9, 19.3, 19.2, 19.1, 19.0. HRMS (ESI) calcd for $\mathrm{C}_{39} \mathrm{H}_{55} \mathrm{~N}_{4} \mathrm{O}_{9}[\mathrm{M}+\mathrm{H}]^{+}: 723.3969$, found 723.3978 .

\subsection{Synthesis of compound 33}

To a solution of compound $32(0.13 \mathrm{~g}, 0.18 \mathrm{mmol})$ in EtOH $(10 \mathrm{~mL})$ and $\mathrm{H}_{2} \mathrm{O}(1 \mathrm{~mL})$ were added $\mathrm{NH}_{4} \mathrm{Cl}(0.15 \mathrm{~g}$, $2.8 \mathrm{mmol})$ and $\mathrm{Fe}(0.10 \mathrm{~g}, 1.8 \mathrm{mmol})$. The mixture was stirred at $80{ }^{\circ} \mathrm{C}$ for $12 \mathrm{~h}$. After workup, the crude product was subjected to column chromatography (dichloromethane/methanol, $V: V=25: 1)$ to 5 -amino- $N$-(2,4-diisobutoxy-5-((4-isobutoxypyridin-3-yl)carbamoyl)phenyl)2,4-diisobutoxybenzamide (33) as a pale solid (84 $\mathrm{mg}$, 69\%). m.p. $181.3 \sim 181.9{ }^{\circ} \mathrm{C} ;{ }^{1} \mathrm{H}$ NMR (400 MHz, $\mathrm{CDCl}_{3}$ ) $\delta: 9.75(\mathrm{~s}, 1 \mathrm{H}), 9.71(\mathrm{~s}, 1 \mathrm{H}), 9.65(\mathrm{~s}, 1 \mathrm{H}), 8.92(\mathrm{~s}, 1 \mathrm{H}), 8.25$ $(\mathrm{s}, 1 \mathrm{H}), 7.61(\mathrm{~s}, 1 \mathrm{H}), 7.26(\mathrm{~s}, 1 \mathrm{H}), 6.82(\mathrm{~s}, 1 \mathrm{H}), 6.53(\mathrm{~s}, 1 \mathrm{H})$, $6.45(\mathrm{~s}, 1 \mathrm{H}), 3.78 \sim 3.89(\mathrm{~m}, 10 \mathrm{H}), 2.09 \sim 2.23(\mathrm{~m}, 5 \mathrm{H})$, $0.99 \sim 1.08(\mathrm{~m}, 30 \mathrm{H}) ;{ }^{13} \mathrm{C}$ NMR $\left(100 \mathrm{MHz}, \mathrm{CDCl}_{3}\right) \delta$ : $163.6,163.2,154.4,154.1,153.7,150.8,150.2,145.4$, $142.9,130.6,127.1,122.1,117.5,115.0,114.9,106.5,98.8$, 97.9,77.6, 76.8, 75.3, 74.9, 74.8, 28.3, 28.2, 28.1, 27.9, 19.4, 19.3, 19.2, 19.1. HRMS (ESI) calcd for $\mathrm{C}_{39} \mathrm{H}_{57} \mathrm{~N}_{4} \mathrm{O}_{7}[\mathrm{M}+$ $\mathrm{H}]^{+}:$693.4227, found 693.4238 .

\subsection{Synthesis of compound 34}

To a solution of $16(70 \mathrm{mg}, 0.21 \mathrm{mmol})$ in dichloromethane $(5 \mathrm{~mL})$ and DMF $(0.05 \mathrm{~mL})$ was added $(\mathrm{COCl})_{2}$ $(0.2 \mathrm{~mL}, 4.8 \mathrm{mmol})$. The mixture was stirred at room temperature for $4 \mathrm{~h}$. After workup, the resulting acyl chloride 17 was dissolved in dichloromethane $(5 \mathrm{~mL})$. The solution was then added to a solution of $\mathbf{3 3}(71 \mathrm{mg}, 0.10 \mathrm{mmol})$ and triethylamine $(63 \mathrm{mg}, 0.68 \mathrm{mmol})$ in dichloromethane $(5$ $\mathrm{mL})$. The solution was stirred at room temperature for $2 \mathrm{~h}$. After workup, the crude product obtained was subjected to column chromatography (dichloromethane/methanol, $V: V=30: 1)$ to afford 5-((5-)((2,4-diisobutoxy-5-((4-iso- 
butoxypyridin-3-yl)carbamoyl)phenyl)carbamoyl)-2,4-diisobutoxyphenyl)carbamoyl)-2,4-diisobutoxybenzyl acetate (34) as a white solid (93 mg, 87\%). m.p. 173.4 $173.7{ }^{\circ} \mathrm{C} ;{ }^{1} \mathrm{H}$ NMR $\left(400 \mathrm{MHz}, \mathrm{CDCl}_{3}\right) \delta: 9.68(\mathrm{~s}, 1 \mathrm{H}), 9.65$ $(\mathrm{s}, 1 \mathrm{H}), 9.47(\mathrm{~s}, 2 \mathrm{H}), 8.93(\mathrm{~s}, 1 \mathrm{H}), 8.80(\mathrm{~s}, 1 \mathrm{H}), 8.23(\mathrm{~d}, J=$ $4 \mathrm{~Hz}, 1 \mathrm{H}), 6.82(\mathrm{~d}, J=4 \mathrm{~Hz}, 1 \mathrm{H}), 6.55(\mathrm{~s}, 2 \mathrm{H}), 6.47$ (s, 1H), $5.13(\mathrm{~s}, 2 \mathrm{H}), 3.80 \sim 3.95(\mathrm{~m}, 14 \mathrm{H}), 2.08 \sim 2.21(\mathrm{~m}, 10 \mathrm{H})$, $1.03 \sim 1.04(\mathrm{~m}, 42 \mathrm{H}) ;{ }^{13} \mathrm{C} \mathrm{NMR}\left(100 \mathrm{MHz}, \mathrm{CDCl}_{3}\right) \delta$ : $170.0,163.3,163.2,163.1,160.8,158.7,154.9,154.3$, $154.1,153.9,153.7,145.4,142.9,134.3,127.8,127.0$, $125.8,122.1,121.6,117.3,115.6,115.1,114.6,106.5,98.0$, $96.7,77.3,76.9,76.4,75.4,75.3,74.9,74.7,61.5,28.3$, 28.2, 28.1, 27.9, 21.0, 19.4, 19.3, 19.2, 19.1. HRMS (ESI) calcd for $\mathrm{C}_{59} \mathrm{H}_{81} \mathrm{~N}_{4} \mathrm{O}_{12}[\mathrm{M}+\mathrm{H}]^{+}:$1013.5851, found 1013.5848 .

\subsection{Synthesis of compound 35}

To a solution of compound $34(90 \mathrm{mg}, 0.089 \mathrm{mmol})$ in THF $(10 \mathrm{~mL})$ and $\mathrm{H}_{2} \mathrm{O}(1 \mathrm{~mL})$ was added $\mathrm{LiOH} \cdot \mathrm{H}_{2} \mathrm{O}(7.5$ $\mathrm{mg}, 0.18 \mathrm{mmol})$. The mixture was stirred under reflux for 12 h. After workup, the resulting residue was subjected to column chromatography (dichloromethane/methanol, $V$ : $V=20: 1)$ to afford $N$-(2,4-diisobutoxy-5-((4-isobutoxypyridin-3-yl)carbamoyl)phenyl)-5-(5-(hydroxymethyl)-2,4diisobutoxybenzamido)-2,4-diisobutoxybenzamide (35) as a white solid (86 mg, 93\%). m.p. 168.1 $\sim 168.5{ }^{\circ} \mathrm{C} ;{ }^{1} \mathrm{H}$ NMR (400 MHz, $\left.\mathrm{CDCl}_{3}\right) \delta: 9.70(\mathrm{~d}, J=2 \mathrm{~Hz}, 2 \mathrm{H}), 9.47$ (s, $1 \mathrm{H}), 9.43$ (s, 1H), 8.90 (s, 1H), 8.77 (s, 1H), 8.28 (d, $J=2$ $\mathrm{Hz}, 1 \mathrm{H}), 8.18$ (s, 1H), 6.89 (d, $J=2 \mathrm{~Hz}, 1 \mathrm{H}), 6.56$ (s, 1H), $6.49(\mathrm{~s}, 1 \mathrm{H}), 4.70(\mathrm{~s}, 2 \mathrm{H}), 3.94 \sim 3.98(\mathrm{~m}, 8 \mathrm{H}), 3.85 \sim 3.86$ $(\mathrm{m}, 6 \mathrm{H}), 2.10 \sim 2.24(\mathrm{~m}, 7 \mathrm{H}), 1.02 \sim 1.11(\mathrm{~m}, 42 \mathrm{H}) ;{ }^{13} \mathrm{C}$ NMR $\left(100 \mathrm{MHz}, \mathrm{CDCl}_{3}\right) \delta: 163.3,163.2,160.7,158.2$, $154.9,154.5,154.0,153.7,145.5,143.0,133.1,127.8$, $127.0,126.1,125.7,122.5,122.1,121.6,115.4,115.1$, 114.6, 106.5, 98.0, 96.9, 77.3, 76.9, 76.4, 75.3, 74.9, 74.7, 61.4, 28.3, 28.2, 28.1, 27.9, 19.4, 19.3, 19.2, 19.1. HRMS (ESI) calcd for $\mathrm{C}_{55} \mathrm{H}_{79} \mathrm{~N}_{4} \mathrm{O}_{11}[\mathrm{M}+\mathrm{H}]^{+}:$971.5745, found 971.5747.

\subsection{Synthesis of compound 36}

To a solution of compound $35(80 \mathrm{mg}, 0.082 \mathrm{mmol})$ in dichloromethane $(10 \mathrm{~mL})$ was added $\mathrm{MnO}_{2}(0.14 \mathrm{~g}, 1.6$ mmol). The mixture was stirred under reflux for $12 \mathrm{~h}$. After workup, the resulting residue was subjected to column chromatography (dichloromethane/methanol, $\quad V: V=$ $30: 1)$ to afford $N$-(2,4-diisobutoxy-5-((4-isobutoxypyridin-3-yl)-carbamoyl)phenyl)-5-(5-formyl-2,4-diisobutoxybenzamido)-2,4-diisobutoxybenzamide (36) as a white solid (62 mg, 78\%). m.p. 178.2 179.0 ${ }^{\circ} \mathrm{C}$; ${ }^{1} \mathrm{H}$ NMR (400 MHz, $\left.\mathrm{CDCl}_{3}\right) \delta: 10.32(\mathrm{~s}, 1 \mathrm{H}), 9.68(\mathrm{~s}, 1 \mathrm{H}), 9.64(\mathrm{~s}, 1 \mathrm{H}), 9.44(\mathrm{~s}$, $1 \mathrm{H}), 9.16(\mathrm{~s}, 1 \mathrm{H}), 8.92(\mathrm{~s}, 1 \mathrm{H}), 8.72(\mathrm{~s}, 1 \mathrm{H}), 8.67(\mathrm{~s}, 1 \mathrm{H})$, $8.22(\mathrm{~d}, J=-2 \mathrm{~Hz}, 1 \mathrm{H}), 6.81(\mathrm{~d}, J=2 \mathrm{~Hz}, 1 \mathrm{H}), 6.53(\mathrm{~s}, 2 \mathrm{H})$, $6.47(\mathrm{~s}, 1 \mathrm{H}), 3.83 \sim 3.96(\mathrm{~m}, 14 \mathrm{H}), 2.08 \sim 2.26(\mathrm{~m}, 7 \mathrm{H})$, $0.99 \sim 1.07(\mathrm{~m}, 42 \mathrm{H}) ;{ }^{13} \mathrm{C}$ NMR $\left(100 \mathrm{MHz}, \mathrm{CDCl}_{3}\right) \delta$ : $187.6,164.7,163.2,163.0,162.4,155.1,154.4,154.1$, $154.0,153.6,145.4,142.8,134.6,127.9,126.9,125.7$, $122.0,121.0,119.0,115.7,115.3,114.9,106.5,97.9,96.3$, $76.8,76.6,76.2,75.3,75.2,75.0,74.9,28.3,28.2,28.1$,
28.0, 27.8, 19.3, 19.2, 19.1. HRMS (ESI) calcd for $\mathrm{C}_{55} \mathrm{H}_{77} \mathrm{~N}_{4} \mathrm{O}_{11}[\mathrm{M}+\mathrm{H}]^{+}:$969.5589, found 969.5573.

\subsection{Synthesis of compound 6}

To a solution of compound $\mathbf{3 6}(31 \mathrm{mg}, 0.032 \mathrm{mmol})$ in $\mathrm{MeOH}(5 \mathrm{~mL})$ was added compound 10 (12 mg, 0.032 $\mathrm{mmol})$ and triethylamine $(0.2 \mathrm{~mL})$. The mixture was stirred under reflux for $12 \mathrm{~h}$ and then cooled to room temperature. The precipitate formed was filtered and washed with cold methanol and dried in vacuo to afford (E)-5-(2,4-diisobutoxy-5-((2-(2,3,4-trifluoro-5-iodobenzoyl)hydrazono)methyl)benzamido)- $N$-(2,4-diisobutoxy-5-((4-isobutoxypyridin-3-yl)carbamoyl)phenyl)-2,4-diisobutoxybenzamide (6) as a white solid (20 mg, 50\%). ${ }^{1} \mathrm{H}$ NMR indicated that this compound existed as two configurational isomers in a $1: 0.31$ ratio. m.p. $234.0 \sim 234.8{ }^{\circ} \mathrm{C} ;{ }^{1} \mathrm{H}$ NMR $(400 \mathrm{MHz}$, DMSO- $d_{6}$, major) $\delta: 12.01(\mathrm{~s}, 1 \mathrm{H}), 10.26(\mathrm{~s}, 1 \mathrm{H}), 9.91(\mathrm{~s}$, $1 \mathrm{H}), 9.75(\mathrm{~s}, 1 \mathrm{H}), 9.63(\mathrm{~s}, 1 \mathrm{H}), 9.90(\mathrm{~s}, 1 \mathrm{H}), 8.85(\mathrm{~s}, 1 \mathrm{H})$, $8.63(\mathrm{~s}, 1 \mathrm{H}), 8.59(\mathrm{~s}, 1 \mathrm{H}), 8.55 \sim 8.57(\mathrm{~m}, 1 \mathrm{H}), 7.99 \sim 8.03$ $(\mathrm{m}, 1 \mathrm{H}), 7.67 \sim 7.69(\mathrm{~m}, 1 \mathrm{H}), 7.00(\mathrm{~s}, 1 \mathrm{H}), 6.96(\mathrm{~s}, 1 \mathrm{H})$, $6.87(\mathrm{~s}, 1 \mathrm{H}), 3.99 \sim 4.27(\mathrm{~m}, 14 \mathrm{H}), 2.08 \sim 2.21(\mathrm{~m}, 7 \mathrm{H})$, $1.00 \sim 1.07(\mathrm{~m}, 42 \mathrm{H}) ;{ }^{19} \mathrm{~F}$ NMR $\left(300 \mathrm{MHz}\right.$, DMSO- $d_{6}$, major) $\delta:-110.67 \sim-110.76(\mathrm{~m}, 1 \mathrm{~F}),-134.85 \sim-134.95$ $(\mathrm{m}, 1 \mathrm{~F}),-156.15 \sim-156.27(\mathrm{~m}, 1 \mathrm{~F}) ;{ }^{1} \mathrm{H}$ NMR $(400$ $\mathrm{MHz}, \mathrm{DMSO}-d_{6}$, minor) $\delta: 12.16(\mathrm{~s}, 1 \mathrm{H}), 10.26(\mathrm{~s}, 1 \mathrm{H})$, $9.89(\mathrm{~s}, 1 \mathrm{H}), 9.60 \sim 9.61(\mathrm{~m}, 2 \mathrm{H}), 8.96(\mathrm{~s}, 1 \mathrm{H}), 8.67(\mathrm{~s}, 1 \mathrm{H})$, $8.55 \sim 8.57(\mathrm{~m}, 1 \mathrm{H}), 8.46(\mathrm{~s}, 1 \mathrm{H}), 8.09(\mathrm{~s}, 1 \mathrm{H}), 7.86(\mathrm{~s}, 1 \mathrm{H})$, $7.67 \sim 7.69(\mathrm{~m}, 1 \mathrm{H}), 7.00(\mathrm{~s}, 1 \mathrm{H}), 6.93(\mathrm{~s}, 1 \mathrm{H}), 6.83(\mathrm{~s}, 1 \mathrm{H})$, $3.99 \sim 4.27(\mathrm{~m}, 14 \mathrm{H}), 2.08 \sim 2.21(\mathrm{~m}, 7 \mathrm{H}), 1.00 \sim 1.07(\mathrm{~m}$, $42 \mathrm{H}) ;{ }^{19} \mathrm{~F}$ NMR (300 MHz, DMSO- $d_{6}$, minor $) \delta$ : $111.73 \sim-111.82(\mathrm{~m}, 1 \mathrm{~F}),-132.15 \sim-132.25(\mathrm{~m}, 1 \mathrm{~F})$, $-157.14 \sim-157.26(\mathrm{~m}, 1 \mathrm{~F}) ;{ }^{13} \mathrm{C} \mathrm{NMR}(100 \mathrm{MHz}$, DMSO-d $\left._{6}\right) \delta: 163.6,162.8,162.6,161.6,160.2,159.0$, $158.9,157.7,154.8,154.7,153.6,153.3,143.8,140.6$, $140.5,132.8,132.7,129.8,127.3,125.1,124.5,122.3$, $121.7,120.8,115.7,115.2,114.0,112.5,109.8,99.4,99.3$, $98.6,76.9,76.6,76.3,75.6,75.5,75.1,28.3,28.1,28.0$, 27.7, 19.6, 19.4, 19.3, 19.0. HRMS (ESI) calcd for $\mathrm{C}_{62} \mathrm{H}_{79} \mathrm{~N}_{6} \mathrm{O}_{11} \mathrm{~F}_{3} \mathrm{I}[\mathrm{M}+\mathrm{H}]^{+}: 1267.4808$, found 1267.4813 .

Supporting Information General methods, synthesis and characterization of new compounds, additional crystal structures, ${ }^{1} \mathrm{H}$ NMR, ${ }^{13} \mathrm{C}$ NMR and ${ }^{19} \mathrm{~F}$ NMR spectra of new compounds. The Supporting Information is available free of charge via the Internet at http://sioc-journal.cn/.

\section{References}

[1] (a) Huc, I. Eur. J. Org. Chem. 2004, 17

(b) Gong, B. Sci. China Chem. 2010, 53, 45.

(c) Gan, Q.; Wang, Y.; Jiang, H. Curr. Org. Chem. 2011, 15, 1293.

(d) Zhang, D.-W.; Zhao, X.; Hou, J.-L.; Li, Z.-T. Chem. Rev. 2012, 112, 5271 .

(e) Yamato, K.; Kline, M.; Gong, B. Chem. Commun. 2012, 48, 12142 .

(f) Zhang, D.-W.; Zhao, X.; Li, Z.-T. Acc. Chem. Res. 2014, 47, 1961 .

(g) Huo, Y.; Zeng, H. Acc. Chem. Res. 2016, 49, 922.

(h) Zhang, D.-W.; Wang, H.; Li, Z.-T. Prog. Chem. 2020, 32, 1665 (in Chinese). 
(张丹维, 王辉, 黎占亭, 化学进展, Prog. Chem. 2020, 32, 1665.)

[2] (a) Hou, J.-L.; Shao, X.-B.; Chen, G.-J.; Zhou, Y.-X.; Jiang, X.-K.; Li, Z.-T. J. Am. Chem. Soc. 2004, 126, 12386.

(b) Wang, Y.; Xiang, J.; Jiang, H. Chem.-Eur. J. 2011, 17, 613.

(c) Lautrette, G.; Aube, C.; Ferrand, Y.; Pipelier, M.; Blot, V.; Thobie, C.; Kauffmann, B.; Dubreuil, D.; Huc, I. Chem.-Eur. J. 2014, 20, 1547 .

(d) Seo, S. B.; Lee, S.; Jeon, H.-G.; Jeong, K.-S. Angew. Chem. Int. Ed. 2020, 59, 10441.

[3] (a) Li, X.; Wu, Y.-D.; Yang, D. Acc. Chem. Res. 2008, 41, 1428.

(b) Shang, J.; Si, W.; Zhao, W.; Che, Y.; Hou, J.-L.; Jiang, H. Org. Lett. 2014, 16, 4008.

(c) Xin, P.; Zhu, P.; Su, P.; Hou, J.-L.; Li, Z.-T. J. Am. Chem. Soc. 2014, 136, 13078

(d) Qi, S.; Zhang, C.; Yan, T.; Yang, F.; Zhang, J.; Mao, S.; Dong, Z. Macromol. Rapid Commun. 2020, 41, 2000099.

(e) Shen, J.; Fan, J.; Ye, R.; Li, N.; Mu, Y.; Zeng, H. Angew. Chem. Int. Ed. 2020, 59, 13328.

(f) Bai, D.; Wang, S.; Wang, Y.; Fu, J.; Fang, X.; Zhu, J.; Yan, T.; Liu, J. Angew. Chem. Int. Ed. 2020, 59, 13602.

[4] (a) Srinivas, K.; Kauffmann, B.; Dolain, C.; Leger, J.-M.; Ghosez, L.; Huc, Ivan J. Am. Chem. Soc. 2008, 130, 13210.

(b) Yi, H.-P.; Wu, J.; Ding, K.-L.; Jiang, X.-K.; Li, Z.-T. J. Org. Chem. 2007, 72, 870.

(c) Zhao, H.; Shen, J.; Ren, C.; Zeng, W.; Zeng, H. Org. Lett. 2017, 19, 2190.

[5] (a) Cai, W.; Wang, G.-T.; Du, P.; Wang, R.-X.; Jiang, X.-K.; Li, Z.-T. J. Am. Chem. Soc. 2008, 130, 13450 .

(b) Yan, Y.; Qin, B.; Ren, C.; Chen, X.; Yip, Y. K.; Ye, R.; Zhang, D.; Su, H.; Zeng, H. J. Am. Chem. Soc. 2010, 132, 5869.

(c) Liu, C.-Z.; Yan, M.; Wang, H.; Zhang, D.-W.; Li, Z.-T. ACS Omega 2018, 3, 5165.

[6] Chen, F.; Shen, J.; Li, N.; Roy, A.; Ye, R.; Ren, C.; Zeng, H. Angew. Chem. Int. Ed. 2020, 59, 1440 .

[7] (a) Liu, C.-Z.; Koppireddi, S.; Wang, H.; Zhang, D.-W.; Li, Z.-T. Angew. Chem. Int. Ed. 2019, 58, 226.

(b) Liu, C.-Z.; Koppireddi, S.; Wang, H.; Zhang, D.-W.; Li, Z.-T. Chin. Chem. Lett. 2019, 30, 953.

(c) Koppireddi, S.; Liu, C.-Z.; Wang, H.; Zhang, D.-W.; Li, Z.-T. CrystEngComm 2019, 21, 2626.

[8] (a) Aakeröy, C. B.; Champness, N. R.; Janiak, C. CrystEngComm 2010, 12,22 .

(b) Politzer, P.; Murray, J. S. ChemPhysChem 2013, 14, 278.

(c) Xiao, T.; Zhou, L.; Sun, X.-Q.; Huang, F.; Lin, C.; Wang, L. Chin. Chem. Lett. 2020, 31, 1.

(d) Saha, S.; Mishra, M. K.; Reddy, C. M.; Desiraju, G. R. Acc. Chem. Res. 2018, 51, 2957. (e) Wang, B.; Lin, R.-B.; Zhang, Z.; Xiang, S.; Chen, B. J. Am. Chem. Soc. 2020, 142, 14399.

(f) Li, Q.; Li, Z. Acc. Chem. Res. 2020, 53, 962.

(g) Tian, J.; Chen, S.; Wang, X.; Li, J. Chem. Res. Chin. Univ. 2020, 36,151 .

(h) Ding, L.; Wang, Z.-Y.; Wang, J.-Y.; Pei, J. Chin. J. Chem. 2020, 38,13 .

(i) Zhu, Z.-H.; Wang, H.-L.; Zou, H.-H.; Liang, F.-P. Dalton Trans. 2020, 49, 10708

[9] (a) Metrangolo, P.; Neukirch, H.; Pilati, T.; Resnati, G. Acc. Chem. Res. 2005, 38, 386

(b) Wang, H.; Wang, W.; Jin, W. J. Chem. Rev. 2016, 116, 5072.

(c) Xiao, L.; Fu, H. Chem.-Eur. J. 2019, 25, 714.

(d) Liu, C.; Wang, H.; Zhang, D.; Zhao, X.; Li, Z. Chin. J. Org. Chem. 2019, 39, 28 (in Chinese).

(刘传志, 王辉, 张丹维, 黎占亭, 有机化学, 2019, 39, 28.)

(e) Wang, W.; Zhang, Y.; Jin, W. J. Coord. Chem. Rev. 2020, 404, 213107.

(f) Chen, S.; Yin, H.; Wu, J.-J.; Lin, H.; Wang, X.-D. Sci. China Mater. 2020, 63, 1613.

[10] (a) Su, X.; Aprahamian, I. Chem. Soc. Rev. 2014, 43, 1963.

(b) Zhang, D.; Wang, H.; Li, Z. Chem. J. Chin. Univ. 2020, 41, 1139 (in Chinese).

(张丹维, 王辉, 黎占亭, 高等学校化学学报, 2020, 41, 1139.)

(c) Yang, B.; Wang, H.; Zhang, D.-W.; Li, Z.-T. Chin. J. Chem. 2020, 38, 970.

(d) Jiao, T.; Wu, G.; Zhang, Y.; Shen, L.; Lei, Y.; Wang, C.-Y.; Fahrenbach, A. C.; Li, H. Angew. Chem. Int. Ed. 2020, 59, 18350.

[11] (a) Jiang, H.; Léger, J.-M.; Huc, I. J. Am. Chem. Soc. 2003, 125, 3448 .

(b) Zhang, A.; Ferguson, J. S.; Yamato, K.; Zheng, C.; Gong, B. Org. Lett. 2006, 8, 5117.

[12] (a) Li, C.; Ren, S.-F.; Hou, J.-L.; Yi, H.-P.; Zhu, S.-Z.; Jiang, X.-K.; Li, Z.-T. Angew. Chem. Int. Ed. 2005, 44, 5725.

(b) Chopra, D. Cryst. Growth Design 2012, 12, 541.

(c) Chopra, D.; Row, T. N. G. CrystEngComm 2011, 13, 2175.

[13] Isshiki, Y.; Kohchi, Y.; Iikura, H.; Matsubara, Y.; Asoh, K.; Murata, T.; Kohchi, M.; Mizuguchi, E.; Tsujii, S.; Hattori, K.; Miura, T.; Yoshimura, Y.; Aida, S.; Miwa, M.; Saitoh, R.; Murao, N.; Okabe, H.; Belunis, C.; Janson, C.; Lukacs, C.; Schuck, V.; Shimma, N. Bioorg. Med. Chem. Lett. 2011, 21, 1795.

[14] (a) Currie, M.; Speakman, J. C.; Curry, N. A. J. Chem. Soc. A 1967, 1862.

(b) Shukla, R.; Chopra, D. Phys. Chem. Chem. Phys. 2016, 18, 29946.

[15] Ni, T. W.; Tofanelli, M. A.; Ackerson, C. J. Front. Nanosc. 2015, 9 , $2015,103$.

(Fan, Y.) 